\title{
Immunological Aspects of the Tumor Microenvironment and Epithelial-Mesenchymal Transition in Gastric Carcinogenesis
}

\author{
Jacek Baj ${ }^{1, *(\mathbb{D})}$, Karolina Brzozowska ${ }^{2} \mathbb{D}$, Alicja Forma ${ }^{1}\left(\mathbb{D}\right.$, Amr Maani $^{1}$, Elżbieta Sitarz ${ }^{3}(\mathbb{D}$ \\ and Piero Portincasa 4 (D) \\ 1 Chair and Department of Anatomy, Medical University of Lublin, 20-090 Lublin, Poland; \\ aforma@onet.pl (A.F.); amrmaanni@gmail.com (A.M.) \\ 2 Chair and Department of Forensic Medicine, Medical University of Lublin, 20-090 Lublin, Poland; \\ brzozowskakaro@gmail.com \\ 3 Chair and 1st Department of Psychiatry, Psychotherapy and Early Intervention, \\ Medical University of Lublin, Gluska Street 1, 20-439 Lublin, Poland; elzbietaa.sitarz@gmail.com \\ 4 Clinica Medica “A. Murri”, Department of Biomedical Sciences and Human Oncology, \\ University of Bari Aldo Moro, 70124 Bari, Italy; piero.portincasa@uniba.it \\ * Correspondence: jacek.baj@umlub.pl; Tel.: +48-662-094-014
}

Received: 9 March 2020; Accepted: 2 April 2020; Published: 6 April 2020

\begin{abstract}
Infection with Helicobacter pylori, a Gram-negative, microaerophilic pathogen often results in gastric cancer in a subset of affected individuals. This explains why H. pylori is the only bacterium classified as a class I carcinogen by the World Health Organization. Several studies have pinpointed mechanisms by which $H$. pylori alters signaling pathways in the host cell to cause diseases. In this article, the authors have reviewed 234 studies conducted over a span of 18 years (2002-2020). The studies investigated the various mechanisms associated with gastric cancer induction. For the past 1.5 years, researchers have discovered new mechanisms contributing to gastric cancer linked to $H$. pylori etiology. Alongside alteration of the host signaling pathways using oncogenic CagA pathways, $H$. pylori induce DNA damage in the host and alter the methylation of DNA as a means of perturbing downstream signaling. Also, with H. pylori, several pathways in the host cell are activated, resulting in epithelial-to-mesenchymal transition (EMT), together with the induction of cell proliferation and survival. Studies have shown that $H$. pylori enhances gastric carcinogenesis via a multifactorial approach. What is intriguing is that most of the targeted mechanisms and pathways appear common with various forms of cancer.
\end{abstract}

Keywords: gastric cancer; epithelial-mesenchymal transition; immunology; immune cells; carcinogenesis; tumor microenvironment

\section{Introduction}

Gastric cancer (GC) is the fourth most common cancer in the world and occupies the second position regarding cancer-related deaths [1-3]. This is attributed to the high rate of mortality cases among patients [4,5]. Approximately 990,000 patients are diagnosed with GC each year, of which 738,000 are estimated to die of the malignancy [6]. GC has a higher prevalence among males (approximately two to three times as high) compared to females [7]. The prevalence of GC is also highest in East Asia and Europe, compared to North America and some regions in Africa [8].

The causes of GC are multifactorial. Some causative factors may be decisive in the prognosis of patients and further progression of the malignancy. The most common risk factors and predispositions to GC development include belonging to the male gender, old age, family history of the disorder, smoking, 
exposure to radiation, obesity, underlying medical disorders or malfunctions (gastroesophageal reflux disease), unhealthy/poor diet, Helicobacter pylori (H. pylori) infection, genetic factors, or prolonged intake of specific drugs such as non-steroidal anti-inflammatory drugs (NSAIDs) or proton-pump inhibitors (PPIs) [9-12].

Approximately $95 \%$ of all GCs incidents are adenocarcinomas, which may arise either from the gastric mucosa or the most superficial glands of the stomach epithelium [13]. The majority of gastric adenocarcinomas is located in the antrum and body of the stomach and may be classified as diffuse and intestinal carcinomas [14,15]. This classification is based on the Lauren system of classification and depends on its histological features [16-20]. Recently, a molecular classification of GCs was proposed that includes four subtypes of GC-microsatellite instable (MSI), chromosomal instable, Epstein-Barr Virus (EBV) positive and genomically stable [21,22]. Based on recent clinical studies, the prognosis of GC is better among patients who also test positive for EBV within the gastric tumor microenvironment (approximately 9\% of all GCs incidents) [23].

H. pylori infection makes up one of the most relevant factors regarding the development of non-cardia gastric adenocarcinoma [24-27]. Because of its invasive properties, H. pylori is thought to be responsible for one of the highest rates of chronic infections worldwide. Several virulence factors of $H$. pylori contribute to the stomach invasion and development of GC [28-30]. These include cytotoxin-associated gene A (CagA), vacuolating cytotoxin (VacA), or outer inflammatory protein A (OipA) [31]. Furthermore, H. pylori infection may either induce or facilitate further epithelial-mesenchymal transition (EMT) process in the GC microenvironment [32].

Various cell types involved in inflammatory processes exist in the GC microenvironment, including macrophages, neutrophils, fibroblasts, regulatory T-cells ( $\mathrm{T}_{\text {reg }}$ ), B cells, natural killer cells (NK cells), dendritic cells (DCs) or myeloid-derived suppressor cells [26,33-38]. All the aforementioned cells along with their products (cytokines) apply to GC development, its initiation, growth, and induction of metastatic properties [39]. Recent research suggests that chronic inflammation and further GC progression is enhanced not only by the EMT process but also by the proinflammatory microenvironment within the malignancy [39]. Inflammation is considered to play a crucial role in tumor initiation growth and increased metastatic properties of tumor cells [40,41]. Regarding the tumor microenvironment, it consists of tumor cells and stroma, a network of blood vessels and a variety of infiltrating inflammatory cells that significantly promote GC progression [42,43]. Besides, H. pylori infection significantly alters the microenvironment within the gastric stroma, which may eventually lead to chronic gastritis and further GC development [44-46].

\section{Epithelial-Mesenchymal Transition}

EMT refers to the process by which the mesenchymal phenotype is acquired by epithelial cells (ECs) mainly via the reduction of their intracellular adhesions and proliferative capacity (Figure 1.) [47].

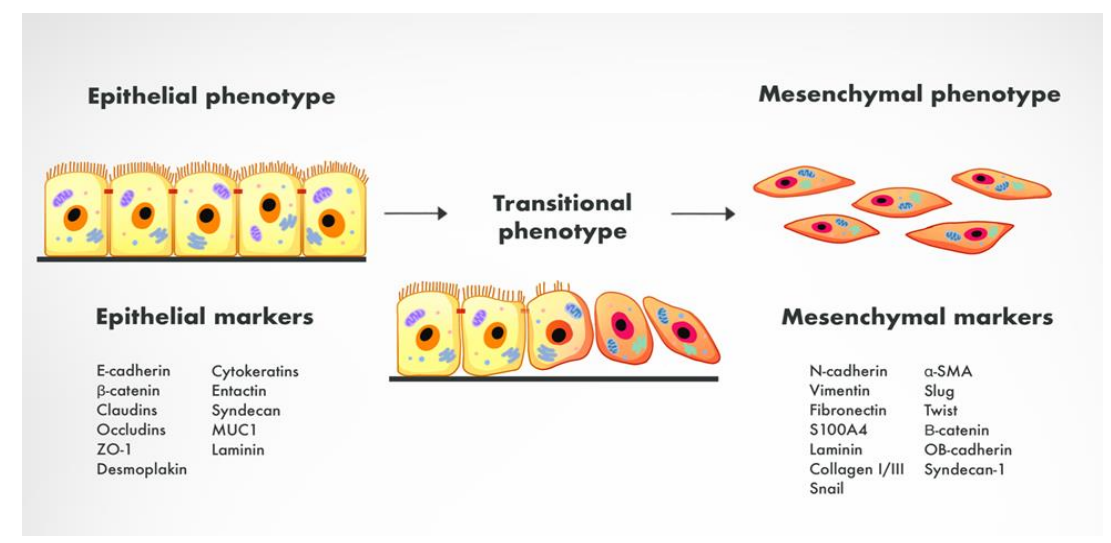

Figure 1. The process of epithelial-mesenchymal transition with specific epithelial and mesenchymal markers. 
Physiologically, EMT can be observed during embryogenesis, tissue development and wound healing [48]. It is also a common phenomenon during carcinogenesis and can either induce or coexist with various malignancies such as breast cancer, thyroid cancer, cholangiocarcinoma, non-small cell lung carcinoma, colorectal cancer, inflammatory bowel disease or GC [49-60]. During the EMT process, ECs undergo a series of biochemical reactions that eventually lead to alterations in the cells' morphology, especially the loss of the polarity of cells $[17,61]$. The entire cell cytoskeleton undergoes reorganization, cell-cell contacts are gradually impaired, and the shape of the cells changes to a spindle-like, more elongated form [62,63]. During EMT, type 1 cadherin (E-cadherin) is switched to neural cadherin (N-cadherin), which disturbs intracellular binding structures including desmosomes and claudins. Thus, the expression of various epithelial markers such as E-cadherin, cytokeratin, laminin-1, desmoplakin or zona-occludens 1 (ZO-1) is significantly lowered [64-67]. On the contrary, increased expression of mesenchymal markers (N-cadherin, vimentin, fibronectin, Snail, Slug, TWIST, $\alpha$-SMA) is observed. EMT enables the acquisition of tumor-initiating cells (TICs) properties by the GC cells along with the development of other malignant features, which is of great importance regarding GC development [68]. Interestingly, EMT is a reversible process-tumor cells that have obtained a mesenchymal phenotype may re-acquire previous epithelial characteristics.

\section{Definition of Epithelial-Mesenchymal Transition in Gastric Cancer}

There is a close relationship between the genesis of GC and EMT, which involves numerous pathomechanisms. Aberrant activation and regulation of GC EMT involves numerous genes, proteins and molecular pathways that are responsible for transcriptional regulation or epigenetic modification. In GC stroma, many cues might influence EMT, among which the WNT5A gene seems crucial as it upregulates EMT-related genes [69]. Besides, Fas signaling promotes motility and metastasis in GC in an EMT-dependent manner [70]. GC EMT can be stimulated by Notch activation and p53 deletion [71]. Other mechanisms include GSK3 $\beta$ inhibition, EphA2 overexpression, Wnt $/ \beta$-catenin signaling activation, aquaporin $3(A Q P 3)$ upregulation, overexpression of epidermal growth factor-like domain-containing protein 7 (EGFL7) and CEACAM6 [72-76]. There is an upregulation of Twist, TGF- $\beta 1$, Slug, Snail, CD44, and vimentin in dysplasia patients or patients with early GC. On the contrary, E-cadherin is greatly decreased in those patients [77]. Usually, E-cadherin levels in GC tissues have a low expression than that in the normal adjacent tissue [78]. Downregulation of E-cadherin is associated with an invasive plus undifferentiated gastric cell phenotype [79]. Increased expression of TWIST1 and vimentin in cancer tissues, as well as a decreased expression of programmed cell death factor 4 (PDCD4), and E-cadherin expression is all linked with malignant tissue degree [80]. EMT-induced cancer stem cell phenotype contributes to the genesis of GC [81]. In gastric epithelia, the stem cells that lie at the base of the pyloric gastric glands depend on an active Wnt pathway, one that is dynamically regulated, and this is characterized by Lgr5 expression [82,83]. Activation of EMT in Run $\times 3^{-/-}$p53 $^{-/-}$gastric epithelial cells is closely followed by the induction of Lgr5 [84]. The loss of Runx3 in gastric epithelial cells induces EMT, which results in a production of a tumorigenic stem cell-like subpopulation with a high expression of Lgr5. Runx3 is deeply involved in the protection of gastric epithelial cells against growth factor signaling and the resulting cellular stemness and plasticity. EMT is linked to cancer stem cells and can induce tumorigenesis and stemness. There is a close association between EMT, GC and chronic inflammation, among which H. pylori infection constitutes a major risk factor [6].

\section{Neutrophils}

\subsection{Tumor-Associated Neutrophils}

Neutrophils are the most abundant leukocyte type that plays a significant role in all immune processes, including cancer progression [85]. Tumor-associated neutrophils (TANs) have been linked to poorer outcomes in various types of cancers [86]. Neutrophils can induce EMT in tumor cells, thereby 
increasing the migratory ability and invasiveness of GC cells [87]. Not only the elevated absolute peripheral blood neutrophil counts but also the neutrophil/lymphocyte ratio, and neutrophil infiltration in the tumor microenvironment, all make up for poor prognosis [55]. The neutrophil/lymphocyte ratio is a significant prognostic factor in GC progression. High neutrophil production appears to be unfavorable to 5 -year survival $[88,89]$. The score of the absolute postoperative number of neutrophils is an important prognostic factor post-surgery. According to Clausen et al. (2020), TANs density makes up an independent predictor of tumor-specific survival only for women that validate the sexual dimorphism of GC [90].

\subsection{IL-17a}

Neutrophils may promote tumor initiation, progression, and metastasis through the release of several cytokines. IL-17a (a member of the IL-17 family), in particular, is significant in autoimmune diseases and inflammatory processes [91,92]. What makes it particularly interesting is that after binding with its IL-17Ra receptor, IL-17a acts through a novel ACT1-dependent pathway, as opposed to the JAK2-STAT3 pathway triggered by Th1 and Th2 cell families [93-95]. The ACT1/TRAF6/NF- $\mathrm{kB}-$ dependent signaling is more characteristic to innate immunity and determines the role of IL-17a in autoimmune pathology, neutrophil recruitment and immunity to extracellular pathogens [96]. While IL-17a does not mediate the JAK2-STAT3 pathway directly, it can activate STAT3 indirectly through AKT signaling, it leads to the production of IL-6 triggering the JAK-STAT pathway [97].

The role of TAN-derived IL-17a in GC has been described in a recent study by Li et al. [98]. The study aimed to explore how TANs influence the migration and invasiveness of GC cells. The (indirect) association between TANs and activation of the JAK2/STAT3 pathway was also studied. The study could establish a positive correlation between neutrophils in GC and prognosis. Means of immunohistochemical staining identified neutrophils to be the main cells behind the production of IL-17a. Neutrophil-induced IL-17a promotes EMT through the activation of the JAK2/STAT3 pathway in GC cells, and this effect can be halted via the use of an IL-17a neutralizing antibody. The authors have found an increased number of neutrophils in GC tissues and the number of neutrophils at the invasion margin was strongly correlated to the TNM stage and lymphovascular and perineural invasion. However, no correlation was found between neutrophil count and age, gender, tumor location, tumor size, Lauren type, or histological grade. Finally, Western blot results showed that neutrophils promote the expression of EMT-related markers in GC cells (vimentin, ZEB1, MKN45, and MKN74), while the expression of E-cadherin was significantly decreased. The opposite was found after adding an IL-17a-neutralizing antibody to the co-culture system. The authors propose the use of an IL-17a neutralizing antibody as a novel therapeutic method in GC therapy. Besides, IL-17a gene polymorphism (e.g., G197A polymorphism) is correlated with increased GC risk [99,100].

\subsection{Bone Marrow Neutrophils}

Neutrophil-cancer cell interaction can lead to the polarization of neutrophils towards a pro-tumor phenotype [101]. Zhang et al. (2017) found that bone marrow neutrophils in mice activated by GC cells promote their ability to migrate, thus leading to increased invasiveness. This is made possible through the activation of the ERK pathway and the induction of EMT. The effects were shown to be decreased by inhibiting the ERK pathway. Further studies are necessary to explore the interaction between neutrophils and gastric cell lines and the effects of TAN-induced EMT on GC cell migration and invasiveness. This might provide innovative new strategies for therapy and treatment. 


\section{Fibroblasts}

\subsection{Cancer-Associated Fibroblasts}

Fibroblasts are one of the many types of cells present in the GC microenvironment. They can originate from different sources: mesenchymal stem cells (MSCs), EMT cells, and tissue-resident cells [102]. Macrophages interact with MSCs and induce differentiation into cancer-associated fibroblasts; this phenomenon is additionally enhanced by $H$. pylori infection [103,104].

Cancer-associated fibroblasts (CAFs) have been shown to have a crucial influence on the initiation, growth, and migration of tumor cells [101]. This is especially due to the reduced cell-to-cell adhesion, enhanced mobility, and constant activation $[87,105]$. CAFs compared to normal fibroblasts (NFs) exhibit an increased proliferation rate with an activated myofibroblastic phenotype and are a crucial component of the tumor stroma [106]. Some phenotypic markers expressed by CAFs include $\alpha$-smooth muscle actin ( $\alpha$-SMA), platelet-derived growth factor receptor- $\beta$ (PDGFR $\beta$ ), fibroblast activation protein (FAP), fibroblast specific protein-1 (FSP-1,) and vimentin [107,108]. The expression of secreted protein acidic and rich in cysteine (SPARC) in CAFs is associated with a better prognosis [109]. The exact molecular mechanisms of cancer promotion by CAFs are unclear. While it has been shown that CAFs are mainly transformed local normal fibroblasts, the underlying molecular mechanisms of the tumor-stromal fibroblasts activation are yet to be explored with GC [106]. Several studies have explored their role in EMT in particular since EMT enhances the transformation of ECs into fibroblast-like cells in a variety of tissues [107]. The extent of CAF's prevalence in GC cells was explored in a 2010 study by Zhi et al. [110]. Immunochemistry staining was used to examine the expression of FSP1, $\alpha$-SMA, and procollagen-1 to determine the prevalence of CAFs and was found to be elevated in tumor specimens compared to normal specimens. The prevalence of CAFs was found to be much higher in metastatic cancers compared to non-metastatic cancers. Still, some studies suggest that CAFs may have a role in inhibiting cancer growth, which further highlights the significance of further research in the field [111].

\subsection{CAFs and Signaling Pathways}

The progression and invasive potential of GC cells are closely associated with the secretion of several cytokines and thus, the activation of various signaling pathways. The cell-to-cell interaction between CAFs and the tumor cells and other surrounding cells including cancer-associated macrophages (CAMs) is essential [112]. In a recent study, CAFs-derived interleukin-33 (IL-33) has been found to mediate the activation of the ERK1/2-SP1-ZEB2 pathway through its receptor ST2L [113]. The secretion of IL-33 by CAFs can be stimulated by TNF- $\alpha$ released by the surrounding GC cells.

CAFs are an ample source of interleukin-6 in the GC environment [114]. This is especially significant in H. pylori-associated GC, where the infection induces cyclooxygenase-2 (COX-2)/prostaglandin E2 signaling pathway. PGE2 may induce the hyper-methylation of miR-149 in CAFs, leading to enhanced IL-6 secretion [115]. Physiologically, IL-6 plays a crucial role in immune and inflammatory responses [116,117]. In the tumor microenvironment, it induces EMT via the activation of the JAK2/STAT3 pathway [118]. Wu et al. have shown that both silencing the IL-6 expression in CAFs and inhibiting the JAK2/STAT3 pathway via a specific inhibitor AG490 reduced tumor metastasis in vivo [114]. Similar results were achieved using an IL-6 neutralizing antibody, all posing potential therapeutic targets to diminish the effects of fibroblasts-induced cancer promotion and growth in the GC microenvironment. Co-culturing GC cells with bone-marrow-derived myofibroblasts (BMFs) has shown high expression of IL-6 and hepatocyte growth factor (HGF) secreted by BMFs, which mediated the secretion of TGF- $\beta 1$ by the surrounding cancer cells [119]. Similar to TANs, CAFs are also a source of IL-17a [120].

Cancer-initiating cells do not exist in isolation but remain in constant interaction with neighboring cells, of which CAFs are of particular significance. CAFs are a source of HGF, TGF- $\beta$, VEGF, FGF, and CXCL12 among others [114]. The expression of IL-8, SDF-1, and HGF by CAFs may be induced by an $H$. pylori infection, as-infected fibroblasts have shown an enhanced expression of Snail1 and 
Twist mRNA [121]. TWIST1 plays a central role in regulating EMT in the cancer microenvironment, influencing the transition of NFs to CAFs with CXCL2 as the target for transcription [122]. HGF induces the activation of its receptor Met tyrosine kinase (TK) and the HGF/Met activation contributes to oncogenesis and GC progression [123]. Using the HGF-neutralizing antibody has inhibited the transition of normal fibroblasts' into CAFs in vivo and in vitro [106]. Significantly increased levels of SDF-1 expression were found in GC CAFs in vivo as well [110]. CAFs may also have the capability of ligand-independent activation of EphA2 (erythropoietin-producing hepatocellular protein A2) through the release of VEGF, which aids in EMT progression [124]. Enhanced expression of galectin-1 in CAFs has been linked to an increase in VEGF in the tumor stroma, a crucial factor in angiogenesis promotion (Figure 2.) [125].

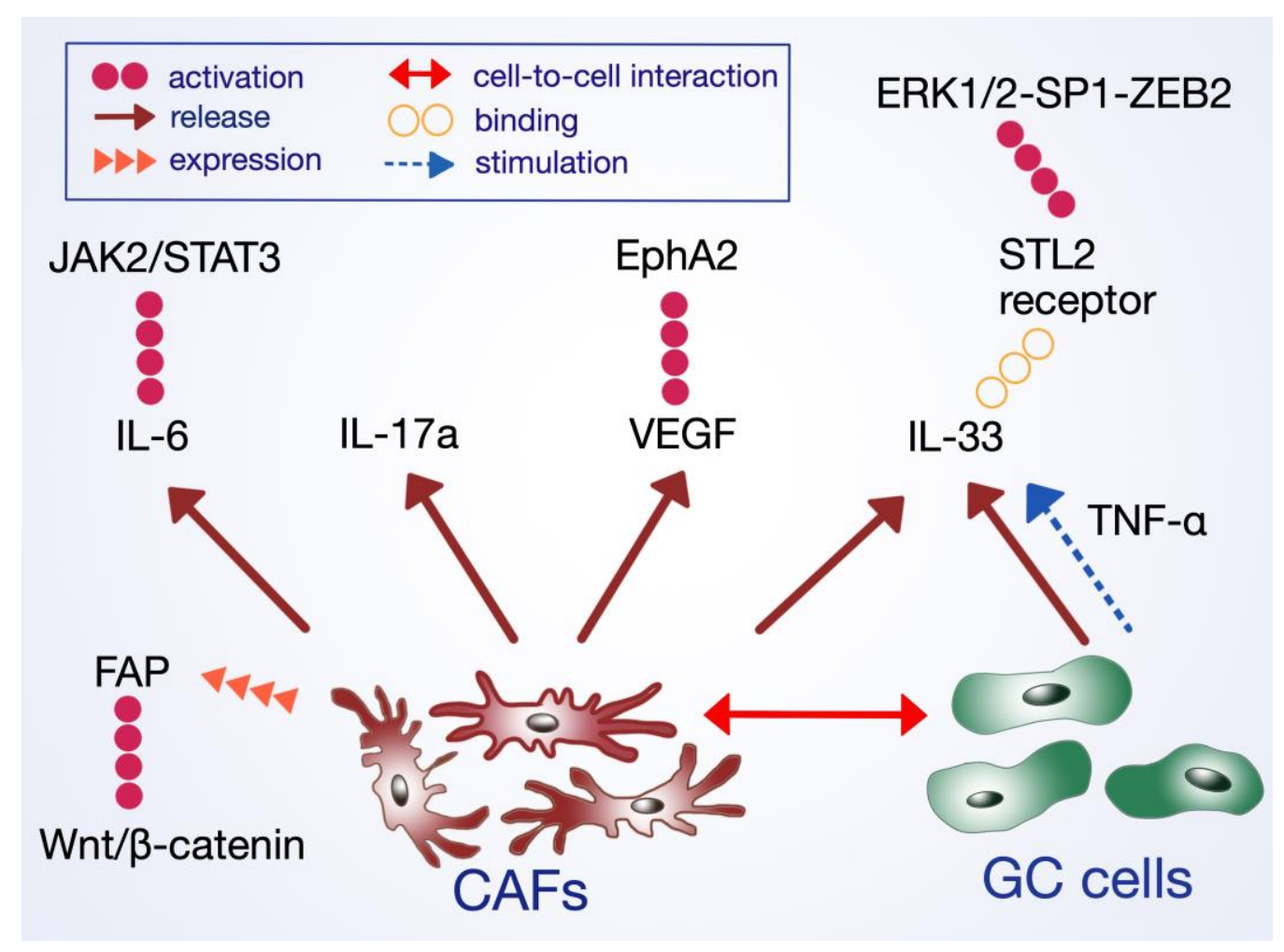

Figure 2. Mechanisms of cancer-associated fibroblasts action in EMT and gastric cancer progression.

A deeper understanding of the role of CAFs in the tumor environment is essential for new-targeted therapy options. CAFs may be a factor in tumor malignancy and developing resistance to 5-fluorouracil [126]. However, several promising potential therapy targets exist in the form of using neutralizing antibodies, JAK2/STAT3 pathway-specific inhibitors, and silencing the expression of pre-cancerous interleukins secreted by CAFs in the tumor microenvironment. Some other options currently discussed include tranilast, which inhibits the TGF- $\beta / S m a d$ pathway and hence EMT, and triptonide, which promotes the production and secretion of tissue inhibitor of metalloproteinase $2[127,128]$. There is a need for further exploration of their role in GC treatment.

\subsection{Normal Fibroblasts Versus CAFs}

There is some controversy on the exact role of normal fibroblasts in the tumor microenvironment. As opposed to CAFs, normal fibroblasts may have a crucial influence on tumor metastasis. In their 2014 study, Xu et al. co-cultured GC cells with dense monolayers of normal fibroblasts at a ratio of 1:10 to mimic the primary environment of cancer metastasis [129]. As a result, some cancer cells morphed to exhibit short, spindle-like morphological characteristics, and increased proliferation and invasion ability. Also, the transformed cancer cells have undergone EMT as shown through the loss 
of E-cadherin and acquisition of vimentin. Kanzawa et al. have proposed that CAFs stimulate the expression of WNT5A in GC cells, which subsequently maintains cancer stem cell properties and induces EMT [130]. Through interaction with tumor stromal cells, CAFs acts as an important modifier of cancer promotion, progression, and metastasis. Normal, non-cancerous fibroblasts have been shown to undergo phenotypic change and exhibit CAF-like traits when grown in vivo in the GC microenvironment [131]. Fibroblast activation protein (FAP) is expressed selectively by CAFs and pericytes in over $90 \%$ of human epithelial cancers, including GC [110]. In a 2009 animal study, Santos et al. showed that FAP-targeted therapy inhibits tumor stroma genesis [132]. FAP has been shown to promote EMT via the $\mathrm{Wnt} / \beta$-catenin signaling pathway, thus facilitating cancer invasiveness and progression [133].

\subsection{Fibroblasts and Tumor Metastasis}

CAFs play a crucial role in the tumor's metastatic potential [134]. They stimulate an epigenetic change in microRNA (miR)-200, reducing its expression and thus promoting cancer invasion and peritoneal dissemination [135]. CAFs themselves show downregulation of miRNA-214 as compared to NFs, which mediates the upregulation of vimentin and thus EMT [136]. However, the ability of tumor cells to migrate and live in healthy tissues may not automatically correspond to the cells' ability to form a metastatic tumor mass. The "traveling tumor cells" hypothesis suggests that cancerous cells may disperse in tissues without forming a metastasis, a notion separate from the circulation of tumor cells and the disseminated tumor cells [137]. Tumor cells that underwent EMT and thus acquired enhanced invasiveness, may then need to undergo the reverse process of mesenchymal-epithelial transition (MET) to form a metastasis away from the primary tumor source. In the environment where fibroblasts underwent MET to gain an epithelial phenotype, a significantly increased amount of suppressor of cancer cell invasion (SCAI) was observed [121]. However, the exact role of SCAI in cancer progression is unclear.

One of the most preferable GC metastasis locations is the liver, which is usually associated with a poor treatment outlook. Also, in a recent study, a close correlation has been shown between the presence of $\alpha$-smooth muscle actin ( $\alpha$-SMA)-positive CAFs in the metastatic stroma and poor patient prognosis [138]. Upon stimulation by TGF-B in the tumor microenvironment, these CAFs were found to secrete lysyl oxidase (LOX), which facilitates tumor growth and progression.

\section{Macrophages}

\subsection{Tumor-Associated Macrophages: M1 and M2 Phenotypes}

Macrophages are among a variety of immune cells present in the GC microenvironment. Their plasticity enables them to play a crucial role in the tumor microenvironment [101,139]. Macrophages can acquire either an M1 (classical) or M2 (alternative) phenotype [85]. Tumor-associated macrophages (TAMs) undergo the M2 activation, a feature essential to their role in tumor growth and progression. The relationship between cancer cells and macrophages is two-fold: cancer cells induce the M2 phenotype differentiation in macrophages, which promotes tumor growth and progression [140]. An M2 predominance was associated with worse overall patient survival [141]. The expression of the PD-1 receptor on M2 macrophages allows for immune escape in cancer cells through interaction with its PD-L1 receptor; also, M2 macrophages can neutralize the effects of pro-inflammatory, anti-tumor M1 macrophages. The secretion of Il- 6 and Il-8 by GC-derived mesenchymal stromal cells and further activation of the JAK2/STAT3 pathway induces the polarization of macrophages into pro-tumor M2 phenotype, which consequently promotes GC metastasis via advancing the EMT process [142]. Likewise, GC metastasis is promoted by matrix metallopeptidase 9 (MMP-9) via the activation of PI3K/AKT/Snail signaling pathway and subsequently induced EMT $[143,144]$. The M2 macrophages mediate a Th2 immunological response, while classical M1 cells promote cancer regression through the Th1 response pathway. Najafi et al. suggest that therapy targeted at phenotype reversal towards 
the classical M1 phenotype in macrophages and blocking the PD-1/PD-1L pathway may be a novel therapy $[140,145]$.

\subsection{Tumor-Associated Macrophages in Gastric Cancer}

In GC patients, high infiltration of TAMs in the tumor microenvironment is associated with poor prognosis and more malignant phenotypes with increased angiogenesis [146-152]. However, the role of M2 macrophages in EMT is unclear. In GC tissues (H. pylori-positive), tumor-infiltrating macrophages express activated mesenchymal-epithelial transition factor (MET) [153]. A 2017 study by Fu et al. has shown a significant correlation between the expression of the CD68 marker characteristic to TAMs and losing expression of the epithelial marker E-cadherin, as well the presence of the mesenchymal marker vimentin [146]. Zhang et al. (2017) proposed increased TAMs infiltration and hypoxia-inducible factor-1 alpha (HIF-1 $\alpha$ ) as potential factors stimulating the induction of EMT [154]. Likewise, TAMs induce the expression of forkhead box Q1 (FOXQ1) promoting EMT with invasion and migration properties [155]. However, the exact mechanism of EMT promotion by TAMs is not fully understood.

TAMs can promote the growth of GC, promotion, and infiltration through several signaling pathways. TAMs are linked with the activation of the $\beta$-catenin pathway, one factor promoting cancer cell invasiveness in GC $[156,157]$. This means that the suppression of the $\beta$-catenin pathway could be a possible treatment for GC [158]. M2 macrophages have also been linked to the impairment of NK-cell function via TGF- $\beta$. A decreased amount of NK cells has been found in the GC microenvironment with ample TAMs present (Figure 3.) [159].

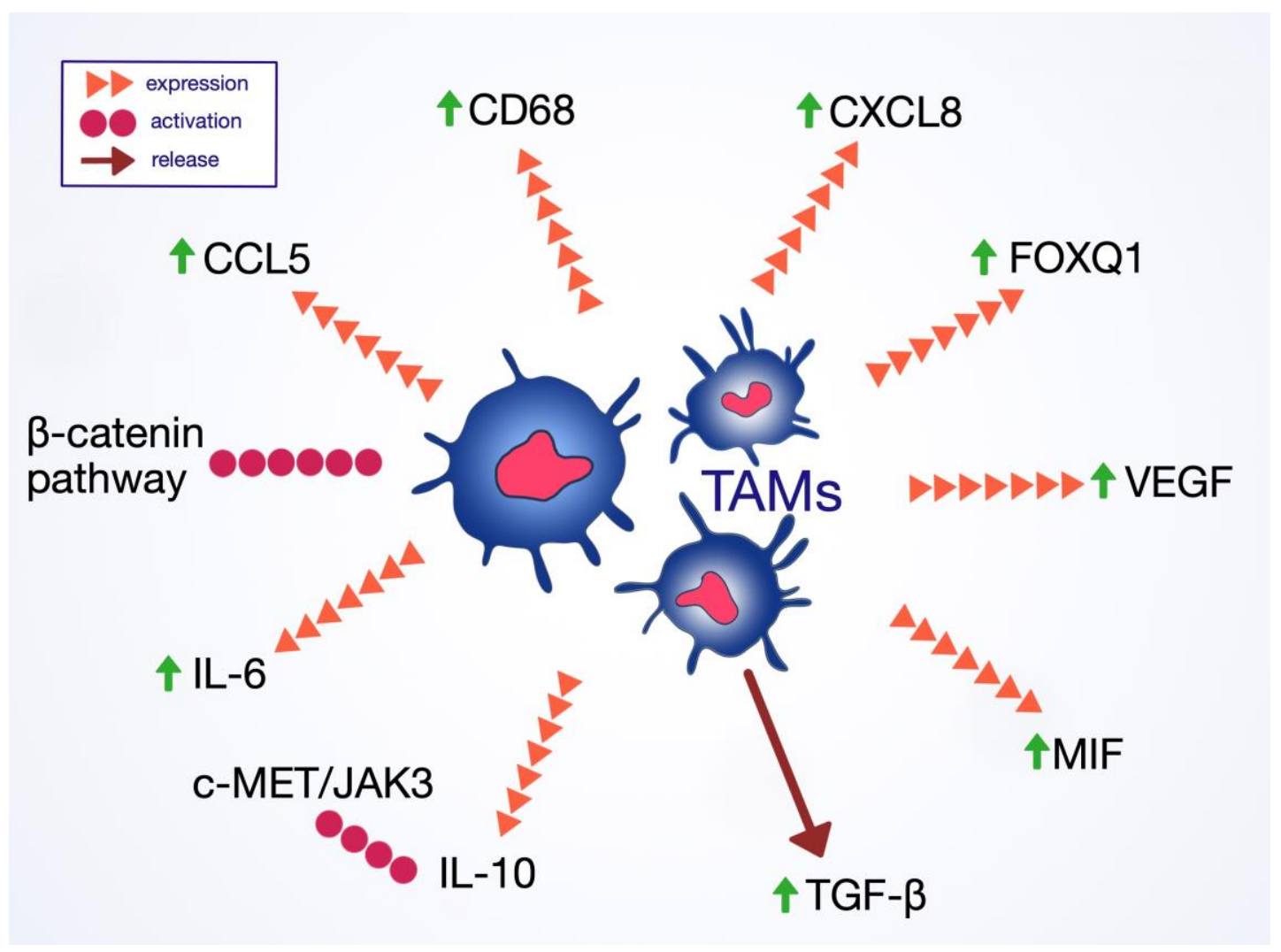

Figure 3. Involvement of tumor-associated macrophages in EMT and gastric cancer progression.

TAMs produce several factors promoting angiogenesis and lymphangiogenesis in GC [106,160,161]. An increased presence of macrophages in the tumor microenvironment is associated with a higher expression of vascular endothelial growth factor (VEGF) and VEGF-C. Macrophage migration inhibitory factor (MIF) makes up an essential link between chronic inflammation and further gastric carcinogenesis 
due to the promotion of EMT and cellular transformation [162]. Various interleukins expressed by TAMs are also associated with tumor progression and prognosis, including IL-6, IL-10, CCL5, and CXCL8. IL-6 present in the tumor microenvironment induces the M2 phenotype differentiation in macrophages through the activation of the STAT3 pathway [146]. IL-6 secreted by intraperitoneal TAMs promotes peritoneal dissemination of GC [163]. CXCL-8 present in the GC stroma is secreted mostly by macrophages, leading to an increased expression of PD-L1 on their surface [164]. This reduces CD8+ T-cells infiltration and impairs the anti-tumor immune response. Macrophages are a significant source of IL-10 in GC. The levels of IL-10 are significantly increased in both the tumor tissue and serum of GC patients. IL-10 has been found to influence GC invasiveness and migratory ability in vitro through the activation of the c-MET/JAK3 pathway [165]. Finally, there is a positive correlation between high expression of CCL5 and CD68 in GC cells. CCL5 promotes cancer growth and proliferation and may serve as another potential therapeutic target [166]. It was observed that docking protein-1 (DOK1) positivity in stromal cells correlates with increased levels of nitric oxide synthase in CD68+ TAMs and thus, poor prognosis [167]. Besides, legumain (tumor-promoting protein) in TAMs is suggested to play a crucial role in the proliferation and invasion of GC cells [168].

Since the level of infiltration of TAMs has a direct correlation with survival outcomes, it can serve as an independent prognostic factor in GC [146]. TAMs have been used as biomarkers in many cancers to date and have shown great potential in serving as prognostic biomarkers in GC as well [169]. Potential TAM-targeted therapy could be another treatment option for GC patients [170].

\section{Interleukin-23 and STAT3 Pathway}

\subsection{Interleukin-23}

Interleukin-23 (IL-23) is a heterodimeric cytokine, which belongs to the IL-12 cytokine family [171]. Over the last decade, a significant role was assigned to IL-23 in terms of the induction and progression of inflammation and inflammatory diseases. A heterodimeric IL-23 is produced by the interaction of IL23A and IL12B. The entire process is controlled by the expression of the IL23A gene, which is over-expressed in cases of the inflammation of CagA-positive H. pylori [172]. IL-23 is produced mainly by DCs and myeloid cells via toll-like receptor (TLR) through either exogenous or endogenous signals including damage-associated molecular patterns (DAMPs), pathogen-associated molecular patterns (PAMPs) or tumor-associated factors [173-175]. IL-23 has a high affinity to the IL-23R presented on various immune cells including T cells, monocytes, DCs or NK cells $[176,177]$. Because of the induction of inflammation and angiogenesis in tissues, IL-23 is widely involved in the progression of carcinogenesis. The mechanism of IL-23 action involves the induction of proliferation and expression of Th1 and Th17 cells. It suppresses the antitumor properties of T cells and the antimetastatic functions of NK cells. It was observed that deficiency of IL-23 equals the lower susceptibility of tumor development and metastasis [178]. Particularly, the IL-12/IL-23 axis of inflammation is the potential target for cancer therapy $[175,179]$.

\subsection{IL-23 and Carcinogenesis}

Tumorigenesis is preceded via the activation of several pathways including NF- $\mathrm{kB}$, cGAS-sTING, and STAT3 pathways in particular [180-184]. STAT3 is expressed in a vast number of cells, being responsible for the control of the cellular processes of proliferation, differentiation, survival, and apoptosis. The over-activation of IL-23 depends on the STAT3 pathway activated by the phosphorylation via tyrosine kinase 2 and Janus kinase 2 [185-187]. An elevated level of IL-23 correlates with the poor clinical outcome and prognosis of cancer-dependent patients [188,189]. The prolonged over-activation of the STAT3 pathway, particularly in malignant cells, controls the survival and proliferation rates via Bcl- $\mathrm{X}_{\mathrm{L}}, \mathrm{Bcl}-2$, Mcl1, c-Myc, Survivin, or Cyclin D1 levels [190-193]. STAT3 induces the transcription of various oncoproteins and transcription factors and IL-6/JAKs, EGFR or Src in a process of dysregulation and further deletion of regulatory proteins [194]. 
IL-23 is involved in the induction of the STAT3 pathway and EMT within gastric cells [195]. IL-23 is mainly secreted with other interleukins including IL-1 $\beta$, IL-6, IL-10, IL-12p40 or IL-12p70 by macrophages; IL-23 is also released by T cells and GC cells [196]. Particularly, IL-17 and IL-23 are highly abundant in cases of advanced gastritis and GC incidents related to H. pylori infection [197-200]. It was reported that the expression of IL-23 receptor (IL-23R) is much higher in GC tissues compared to adjacent, not affected tissues. Also, the level of IL-23 is increased in the serum of patients with GC [201]. The attachment of IL-23 with its receptor intensifies the migration and invasion properties of GC cells mainly by the induction of the STAT3 pathway and further EMT processes. The proliferation rate of cells is independent of the IL-23 level. The higher quantity of IL-23R within GC tissues is associated with larger tumor size and worse clinical outcomes. The infection of VacA-positive H. pylori strains results in the increased number of Th17 cells in the lamina propria of gastric mucosa, which depends on the IL-23 level according to the mice model [202]. Also, susceptibility to GC may be enhanced by micro-RNA binding site single-nucleotide polymorphisms (SNPs) within the IL-23/IL-17 pathway [203]. Regarding the polymorphisms within IL-23R specifically, two genotypes, rs1884444 and rs6682925, are associated with the poorer prognosis of GC patients [204]. Increased level of IL-23 stimulates the further release of IL-17 via activation of IL-17A/IL-17RA/NF- $\mathrm{KB}$ signaling within the GC microenvironment. Since IL-23 levels are also detectable in the serum of affected patients, it was hypothesized that IL-23A concentration may make up a potential indicator of poor prognosis of GC [205]. Regarding the blood biomarkers of GC, disintegrin and metalloproteinase-8 are considered being useful, since their levels are highly correlated with IL-23 levels in blood [206]. There is a correlation between IL-23 level and many mesenchymal and embryonic stem cells in patients with GC $[207,208]$.

\section{Mesenchymal Stem Cell-Derived IL-15}

Mesenchymal stem cells within the tumor microenvironment are reprogrammed to a tumor-specific pattern eventually giving rise to GC and EMT progression [209-211]. MSCs are agitated to migrate towards tumor tissues via various factors excreted by tumor cells, including SDF-1, IL-6 or PDFG. Besides migration properties, MSCs develop into tumor-associated MSCs (TA-MSCs) and CAFs [212]. Interestingly, MSCs stimulate angiogenesis because of the secretion of VEGF, PDGF, basic fibroblast growth factor (bFGF), and angiopoietin-1, providing tumor immune escape via the release of TGF- $\beta$ at the same time [213-215]. The secretion of TGF- $\beta$ and SDF-1a mediates the recruitment of CAFs to the tumor microenvironment. The presence of MSCs within tumor microenvironment induces tumor characteristics, the increased metastatic potential of cancer cells and drug resistance. MSCs also promote the proliferation of cancer stem cells (CSCs) within the tumor environment. Secretion of CXCL1, CXCL5, 6 and 7, IL4, IL8, IL10, IL17b, S100A4, and EGF stimulates cancer cells. The differentiation of MSCs into CAFs through the CXCL12/CXCR4 axis induces the EMT process [216].

Recently, the role IL-15 derived from GC MSCs has been investigated in terms of EMT induction and further GC progression. It was reported that IL-15 levels are increased in both serum and tissues of GC patients comparing to control groups. IL-15 is a pleiotropic cytokine that belongs to the 4-a-helical bundle family of cytokines and acts via the attachment to the receptor complex comprising IL15R $\alpha$ (CD215), IL2R $\beta$ (CD122) and the common $\gamma$ (CD132) chains [217]. IL-15 is involved in the control of development, homeostasis, and functions of T cells, NK cells and NK-T cells [218,219]. It is also a vital cytokine for the control of B cells, DCs, macrophages, and mast cell functions. IL-15 acts as a growth factor for both immune and tumor cells. IL-15 derived from GC MSCs enhances the migration properties of gastric cells, influencing the progression of the EMT process [220]. Over-activation of STAT3 and STAT5 pathways also depends on Il-15 levels. GC MSCs-derived IL-15 increases the number of $\mathrm{T}_{\text {reg }}$ cells via the activation STAT5 pathway in CD4+Foxp3+T cells. An elevated number of Foxp $3+\mathrm{T}_{\text {regs }}$ is associated with enhanced tumor metastasis in various cancers. Further, an increased quantity of Foxp3 in CD4+T cells results in an elevated percentage of PD-1 in $\mathrm{T}_{\text {regs }}$. 


\section{Lymphocytes}

The GC microenvironment is characterized by the enriched infiltration of tumor lymphocytes. These stimulate the inflammation processes within the gastric microenvironment via the secretion of various molecules and mediators such as cytokines, chemokines and matrix metalloproteinases. The presence of CD8+ cytotoxic T cells correlates with improved prognosis of GC patients since CD8+ lymphocytes promote antitumor effects [221,222]. Furthermore, CD8+ lymphocytes stimulate the release of proinflammatory Il-17, promoting tumorigenesis and worsening the clinical outcome of GC [223]. Th1, Th2, Treg, and Th17 are all inducers of EMT and can be obtained due to the differentiation of naive CD4+ T helper cells [224]. A high Th1/Th2 ratio correlates with a better prognosis of GC incidents. Likewise, the higher infiltration of Foxp3 $+\mathrm{T}_{\text {regs }}$ equals to poorer prognosis and higher metastasis rates [225]. Further, GC tissue-derived MSCs induce the differentiation of CD4+ cells into $\mathrm{T}_{\text {reg }}$ cells (but not Th17 cells) [226].

It was reported that $\mathrm{PD}^{+}$peripheral $\mathrm{CD} 8^{+} \mathrm{T}$-cells might make up an independent prognostic marker of severity of GC [227]. The downregulation of microRNA-451 (miR-451) in GC tissues is associated with the increased infiltration of $\mathrm{T}$ cells. Subsequently, the increased amount of $\mathrm{T}$ cells results in the further enhanced differentiation of Th17 cells [228]. It was observed that $\mathrm{CD}^{+}{ }^{+} \mathrm{FOXP3}^{+} \mathrm{T}$ cells within GC tissue are more abundant than $\mathrm{CD}^{+}{ }^{+}$FOXP3- $^{-} \mathrm{T}$ cells. $\mathrm{CD} 4^{+} \mathrm{CD} 25^{\text {high }} \mathrm{T}$ cells present higher expression of 10/IFN- $\gamma$ gene and lowered TGF- $\beta$ levels [229]. Li et al. (2019) observed that smaller tumor size correlates with higher expression of peripheral CD4+ and CD8+ cells [230].

Studies have shown that dense tumor-infiltrating lymphocytes (TIL) are associated with improved prognosis in certain immunogenic tumors, and GC is believed to be an immunogenic tumor [231]. High expression of pan-T cells or TILS in tumor tissue had a significant correlation with favorable overall cancer survival. The implication is that the adaptive immunity that's mediated by $\mathrm{T}$ lymphocytes may serve as a potent anti-tumor response via eradication of cancer cells and avoiding tumor growth [232]. In a study involving 200 patients with GC, the CD3, CD8, and CD45RO high-density groups had prolonged survival times compared to the corresponding groups (low-density) [233]. Recently, Lee et al. conducted a study in vitro, which showed that adaptive immune responses might be initiated in the inflammatory microenvironment of gastric tumors, with TILS being able to induce apoptosis in GC models [234]. A release of tumor antigens into the tumor microenvironment via radiotherapy or cytotoxic chemotherapy induces cell-mediated apoptosis through the activation of cytotoxic T-cell lymphocytes.

\section{Conclusions}

While we understand that $H$. pylori was identified as a carcinogen over 20 years ago, medical researchers are still trying to unravel the novel oncogenic mechanisms utilized by this pathogen. H. pylori has great influence over several host pathways to trigger the development of cancer. Although not all the mechanisms are fully understood, evidence suggests that as H. pylori triggers the infection, the response from the host results in the creation of an environment that encourages the development of tumors. Changes are undergone by the cell in response to $H$. pylori infection involving several hallmarks of cancer progression. These include DNA methylation and damage, EMT pathway activation, suppression of tumor suppressors, activation of anti-apoptotic effectors, and pro-proliferative effectors. It is worth noting that $H$. pylori has the potential to target cancer pathways as a means of inducing gastric carcinogenesis.

Author Contributions: Conceptualization, J.B. and P.P.; methodology, J.B. and A.M.; formal analysis, P.P. and K.B.; investigation, A.F., K.B., A.M.; writing—original draft preparation, J.B., K.B., A.F., A.M., E.S.; writing-review and editing, P.P.; visualization, J.B.; supervision, P.P. All authors have read and agreed to the published version of the manuscript.

Funding: This research received no external funding.

Conflicts of Interest: The authors declare no conflict of interest. 


\section{Abbreviations}

\begin{tabular}{|c|c|}
\hline AQP3 & Aquaporin 3 \\
\hline$\alpha-S M A$ & $\alpha$-Smooth Muscle Actin \\
\hline bFGF & Basic Fibroblast Growth Factor \\
\hline BMFs & Bone-Marrow-Derived Myofibroblasts \\
\hline CAFs & Cancer-Associated Fibroblasts \\
\hline CagA & Cytotoxin-Associated Gene A \\
\hline CAMs & Cancer-Associated Macrophages \\
\hline COX-2 & Cyclooxygenase-2 \\
\hline CSCs & Cancer Stem Cells \\
\hline DAMPs & Damage-Associated Molecular Patterns \\
\hline DCs & Dendritic Cells \\
\hline DOK1 & Docking Protein-1 \\
\hline EBV & Epstein-Barr-Virus \\
\hline ECs & Epithelial Cells \\
\hline EGFL7 & Epidermal growth factor-like domain-containing protein 7 \\
\hline EMT & Epithelial-To-Mesenchymal Transition \\
\hline EphA2 & Erythropoietin-Producing Hepatocellular Protein A2 \\
\hline FAP & Fibroblast Activation Protein \\
\hline FOXQ1 & Forkhead Box Q1 \\
\hline FSP-1 & Fibroblast Specific Protein-1 \\
\hline GC & Gastric Cancer \\
\hline H. pylori & Helicobacter Pylori \\
\hline HGF & Hepatocyte Growth Factor \\
\hline HIF-1 $\alpha$ & Hypoxia-Inducible Factor-1 Alpha \\
\hline LOX & Lysyl Oxidase \\
\hline MET & Mesenchymal-Epithelial Transition \\
\hline MIF & Macrophage Migration Inhibitory Factor \\
\hline MMP-9 & Matrix Metallopeptidase 9 \\
\hline MSCs & Mesenchymal Stem Cells \\
\hline MSI & Microsatellite Instable \\
\hline NFs & Normal Fibroblasts \\
\hline NK cells & Natural Killer Cells \\
\hline NSAIDs & Non-Steroidal Anti-Inflammatory Drugs \\
\hline NSCLC & Non-Small Cell Lung Cancer \\
\hline OipA & Outer Inflammatory Protein A \\
\hline PAMPs & Pathogen-Associated Molecular Patterns \\
\hline PDGFR $\beta$ & Platelet-Derived Growth Factor Receptor-B \\
\hline PPIs & Proton-Pump Inhibitors \\
\hline SCAI & Suppressor Of Cancer Cell Invasion \\
\hline SNPs & Single-Nucleotide Polymorphisms \\
\hline SPARC & Secreted Protein Acidic And Rich In Cysteine \\
\hline TA-MSCs & Tumor-Associated Mscs \\
\hline TAMs & Tumor-Associated Macrophages \\
\hline TANs & Tumor-Associated Neutrophils \\
\hline TICs & Tumor-Initiating Cells \\
\hline TIL & Tumor-Infiltrating Lymphocytes \\
\hline TK & Tyrosine Kinase \\
\hline TLR & Toll-Like Receptor \\
\hline Treg & Regulatory T-Cells \\
\hline VacA & Vacuolating Cytotoxin \\
\hline VEGF & Vascular Endothelial Growth Factor \\
\hline $\mathrm{ZO}-1$ & Zona-Occludens 1 \\
\hline
\end{tabular}




\section{References}

1. Sitarz, R.; Skierucha, M.; Mielko, J.; Offerhaus, J.; Maciejewski, R.; Polkowski, W. Gastric cancer: Epidemiology, prevention, classification, and treatment. Cancer Manag Res. 2018, 10, 239-248. [CrossRef] [PubMed]

2. Machlowska, J.; Maciejewski, R.; Sitarz, R. The Pattern of Signatures in Gastric Cancer Prognosis. Int. J. Mol. Sci. 2018, 19, 1658. [CrossRef] [PubMed]

3. Zanussi, S.; Basaglia, G.; Casarotto, M.; Tedeschi, R.; Fornasarig, M.; Maiero, S.; Canzonieri, V.; De Re, V.; De Paoli, P.; Cannizzaro, R.P. 1.122: Autoimmune Chronic Atrophic Gastritis and Helicobacter Pylori: Prevalence of the Infection and Genetic Heterogeneity. Dig. Liver Dis. 2011, 43, S188. [CrossRef]

4. Jemal, A.; Center, M.M.; DeSantis, C.; Ward, E.M. Global patterns of cancer incidence and mortality rates and trends. Cancer Epidemiol. Biomark. Prev. 2010, 19, 1893-1907. [CrossRef] [PubMed]

5. Bray, F.; Ren, J.S.; Masuyer, E.; Ferlay, J. Global estimates of cancer prevalence for 27 sites in the adult population in 2008. Int. J. Cancer 2013, 132, 1133-1145. [CrossRef] [PubMed]

6. Ferlay, J.; Shin, H.R.; Bray, F.; Forman, D.; Mathers, C.; Parkin, D.M. Estimates of worldwide burden of cancer in 2008: GLOBOCAN 2008. Int. J. Cancer 2010, 127, 2893-2917. [CrossRef] [PubMed]

7. Crew, K.D.; Neugut, A.I. Epidemiology of gastric cancer. World J. Gastroenterol. 2006, 12, 354. [CrossRef]

8. Forman, D.; Burley, V.J. Gastric cancer: Global pattern of the disease and an overview of environmental risk factors. Best Pract. Res. Clin. Gastroenterol. 2006, 20, 633-649. [CrossRef]

9. Karimi, P.; Islami, F.; Anandasabapathy, S.; Freedman, N.; Kamangar, F. Gastric Cancer: Descriptive Epidemiology, Risk Factors, Screening, and Prevention. Cancer Epidemiol. Biomark. Prev. 2014, 23, 700-713. [CrossRef]

10. Cheung, K.; Leung, W. Long-term use of proton-pump inhibitors and risk of gastric cancer: A review of the current evidence. Adv. Gastroenterol. 2019, 12, 175628481983451. [CrossRef]

11. De Re, V.; Repetto, O.; Zanussi, S.; Garziera, M.; Zorzi, M.; Casarotto, M.; Giacomini, S.; Basaglia, G.; Maiero, S.; Toffoli, G.; et al. Mo1577 Different Protein Expression and Genes Patterns of Helicobater Pylori in Pathological Disorders of the Gastric Mucosa. Gastroenterology 2012, 142, 633. [CrossRef]

12. De Re, V.; Orzes, E.; Canzonieri, V.; Maiero, S.; Fornasarig, M.; Alessandrini, L.; Cervo, S.; Steffan, A.; Zanette, G.; Mazzon, C.; et al. Pepsinogens to Distinguish Patients With Gastric Intestinal Metaplasia and Helicobacter pylori Infection Among Populations at Risk for Gastric Cancer. Clin. Transl. Gastroenterol. 2016, 7. [CrossRef] [PubMed]

13. Dicken, B.; Bigam, D.; Cass, C.; Mackey, J.; Joy, A.; Hamilton, S. Gastric Adenocarcinoma. Ann. Surg. 2005, 241, 27-39. [CrossRef] [PubMed]

14. den Hoed, C.M.; Kuipers, E.J. Gastric Cancer: How Can We Reduce the Incidence of this Disease? Curr. Gastroenterol. Rep. 2016, 18, 1-8. [CrossRef]

15. Ansari, S.; Gantuya, B.; Tuan, V.; Yamaoka, Y. Diffuse Gastric Cancer: A Summary of Analogous Contributing Factors for Its Molecular Pathogenicity. Int. J. Mol. Sci. 2018, 19, 2424. [CrossRef]

16. Ma, J.; Shen, H.; Kapesa, L.; Zeng, S. Lauren classification and individualized chemotherapyin gastric cancer (Review). Oncol. Lett. 2016, 11, 2959-2964. [CrossRef]

17. Bure, I.V.; Nemtsova, M.V.; Zaletaev, D.V. Roles of E-cadherin and Noncoding RNAs in the Epithelial-mesenchymal Transition and Progression in Gastric Cancer. Int. J. Mol. Sci. 2019, $20,2870$. [CrossRef]

18. Tirino, G.; Pompella, L.; Petrillo, A.; Laterza, M.M.; Petrillo, A.; Caterino, M.; Orditura, M.; Ciardiello, F.; Galizia, G.; De Vita, F. What's New in Gastric Cancer: The Therapeutic Implications of Molecular Classifications and Future Perspectives. Int. J. Mol. Sci. 2018, 19, 2659. [CrossRef]

19. Re, V.D. Molecular Features Distinguish Gastric Cancer Subtypes. Int. J. Mol. Sci. 2018, 19, 3121. [CrossRef]

20. Alessandrini, L.; Manchi, M.; Re, V.D.; Dolcetti, R.; Canzonieri, V. Proposed Molecular and miRNA Classification of Gastric Cancer. Int. J. Mol. Sci. 2018, 19, 1683. [CrossRef]

21. Ršcken, C. Molecular classification of gastric cancer. Expert Rev. Mol. Diagn. 2017, 17, 293-301. [CrossRef] [PubMed]

22. Waldum, H.; Fossmark, R. Types of Gastric Carcinomas. Int. J. Mol. Sci. 2018, 19, 4109. [CrossRef] [PubMed]

23. Camargo, M.C.; Kim, W.-H.; Chiaravalli, A.M.; Kim, K.-M.; Corvalán, A.H.; Matsuo, K.; Yu, J.; Sung, J.J.; Herrera-Goepfert, R.; Meneses-Gonzalez, F.; et al. Improved survival of gastric cancer with tumour Epstein-Barr virus positivity: An international pooled analysis. Gut 2014, 63, 236-243. [CrossRef] [PubMed] 
24. Ang, T.L.; Fock, K.M. Clinical epidemiology of gastric cancer. Singap. Med. J. 2014, 55, 621-628. [CrossRef] [PubMed]

25. Tsukamoto, T.; Nakagawa, M.; Kiriyama, Y.; Toyoda, T.; Cao, X. Prevention of Gastric Cancer: Eradication of Helicobacter Pylori and Beyond. Int. J. Mol. Sci. 2017, 18, 1699. [CrossRef] [PubMed]

26. Leone, P.; Re, V.D.; Vacca, A.; Dammacco, F.; Racanelli, V. Cancer treatment and the KIR-HLA system: An overview. Clin. Exp. Med. 2017, 17, 419-429. [CrossRef] [PubMed]

27. De Re, V.; Repetto, O.; De Zorzi, M.; Casarotto, M.; Tedeschi, M.; Giuffrida, P.; Lenti, M.V.; Magris, R.; Miolo, G.; Mazzon, C.; et al. Polymorphism in Toll-Like Receptors and Helicobacter Pylori Motility in Autoimmune Atrophic Gastritis and Gastric Cancer. Cancers 2019, 11, 648. [CrossRef]

28. Cannizzaro, R.; Zanussi, S.; Canzonieri, V.; Basaglia, G.; De Re, V.; Fornasarig, M.; Maiero, S.; Orzes, E.; De Paoli, P. Sa1870 Helicobacter pylori Virulence Factors in First Degree Relatives of Gastric Cancer Patients. Gastroenterology 2013, 144. [CrossRef]

29. Repetto, O.; Zanussi, S.; Casarotto, M.; Canzonieri, V.; De Paoli, P.; Cannizzaro, R.; De Re, V. Differential Proteomics of Helicobacter pylori Associated with Autoimmune Atrophic Gastritis. Mol. Med. 2013, 20, 57-71. [CrossRef]

30. Casarotto, M.; Pratesi, C.; Bidoli, E.; Maiero, S.; Magris, R.; Steffan, A.; Basaglia, G.; Canzonieri, V.; De Re, V.; Cannizzaro, R.; et al. Differential Helicobacter pylori Plasticity in the Gastric Niche of Subjects at Increased Gastric Cancer Risk. Pathogens 2019, 8, 65. [CrossRef]

31. Wang, F.; Meng, W.; Wang, B.; Qiao, L. Helicobacter pylori-induced gastric inflammation and gastric cancer. Cancer Lett. 2014, 345, 196-202. [CrossRef] [PubMed]

32. Zhang, Q.; Ding, J.; Liu, J.; Wang, W.; Zhang, F.; Wang, J.; Li, Y. Helicobacter pylori-infected MSCs acquire a pro-inflammatoryphenotype and induce human gastric cancer migration by promoting EMT in gastric cancer cells. Oncol. Lett. 2016, 11, 449-457. [CrossRef] [PubMed]

33. Zeng, D.; Li, M.; Zhou, R.; Zhang, J.; Sun, H.; Shi, M.; Bin, J.; Liao, Y.; Rao, J.; Liao, W. Tumor microenvironment characterization in gastric cancer identifies prognostic and immunotherapeutically relevant gene signatures. Cancer Immunol. Res. 2019, 7, 737-750. [CrossRef] [PubMed]

34. Li, L.; Ouyang, Y.; Wang, W.; Hou, D.; Zhu, Y. The landscape and prognostic value of tumor-infiltrating immune cells in gastric cancer. PeerJ 2019, 7, e7993. [CrossRef] [PubMed]

35. Uppal, A.; Dehal, A.; Chang, S.-C.; Jalas, J.R.; Bilchik, A.J. The Immune Microenvironment Impacts Survival in Western Patients with Gastric Adenocarcinoma. J. Gastrointest. Surg. 2019, 24, 28-38. [CrossRef]

36. Jiang, Y.; Xie, J.; Huang, W.; Chen, H.; Xi, S.; Han, Z.; Huang, L.; Lin, T.; Zhao, L.-Y.; Hu, Y.-F.; et al. Tumor Immune Microenvironment and Chemosensitivity Signature for Predicting Response to Chemotherapy in Gastric Cancer. Cancer Immunol. Res. 2019, 7, 265-273. [CrossRef]

37. Lazăr, D.C.; Avram, M.F.; Romoșan, I.; Cornianu, M.; Tăban, S.; Goldiș, A. Prognostic significance of tumor immune microenvironment and immunotherapy: Novel insights and future perspectives in gastric cancer. World J. Gastroenterol. 2018, 24, 3583-3616. [CrossRef]

38. Dolcetti, R.; Re, V.D.; Canzonieri, V. Immunotherapy for Gastric Cancer: Time for a Personalized Approach? Int. J. Mol. Sci. 2018, 19, 1602. [CrossRef]

39. Ma, H.Y.; Liu, X.Z.; Liang, C.M. Inflammatory microenvironment contributes to epithelial-mesenchymal transition in gastric cancer. World J. Gastroenterol. 2016, 22, 6619-6628. [CrossRef]

40. Elinav, E.; Nowarski, R.; Thaiss, C.A.; Hu, B.; Jin, C.; Flavell, R.A. Inflammation-induced cancer: Crosstalk between tumours, immune cells and microorganisms. Nat. Rev. Cancer 2013, 13, 759-771. [CrossRef]

41. Liao, C.-P.; Booker, R.C.; Brosseau, J.-P.; Chen, Z.; Mo, J.; Tchegnon, E.; Wang, Y.; Clapp, D.W.; Le, L. Contributions of inflammation and tumor microenvironment to neurofibroma tumorigenesis. J. Clin. Investig. 2018, 128, 2848-2861. [CrossRef] [PubMed]

42. Hui, L.; Chen, Y. Tumor microenvironment: Sanctuary of the devil. Cancer Lett. 2015, 368, 7-13. [CrossRef] [PubMed]

43. Kim, J.; Bae, J.S. Tumor-associated macrophages and neutrophils in tumor microenvironment. Mediat. Inflamm. 2016, 2016, 1-11. [CrossRef] [PubMed]

44. Velin, D.; Straubinger, K.; Gerhard, M. Inflammation, immunity, and vaccines for Helicobacter pylori infection. Helicobacter 2016, 21 (Suppl. 1), 26-29. [CrossRef] [PubMed]

45. Shamsdin, S.A.; Alborzi, A.; Ghaderi, A.; Lankrani, K.B.; Pouladfar, G.R. Significance of TC9 and TH9 in Helicobacter pylori-induced gastritis. Helicobacter 2019, 25, e12672. [CrossRef] [PubMed] 
46. Zhang, Y.; Yan, J.; Li, C.; Wang, X.; Dong, Y.; Shen, X.; Zhang, X. LncRNA H19 induced by helicobacter pylori infection promotes gastric cancer cell growth via enhancing NF-kB-induced inflammation. J. Inflamm. 2019, 16, 23. [CrossRef] [PubMed]

47. Sannino, G.; Marchetto, A.; Kirchner, T.; Grźnewald, T.G.P. Epithelial-to-mesenchymal and mesenchymal-to-epithelial transition in mesenchymal tumors: A paradox in sarcomas? Cancer Res. 2017, 77, 4556-4561. [CrossRef]

48. Kalluri, R.; Weinberg, R. The basics of epithelial-mesenchymal transition. J. Clin. Investig. 2010, $120,1786$. [CrossRef]

49. Gašparović, A.; Čipak; Milković, L.; Dandachi, N.; Stanzer, S.; Pezdirc, I.; Vrančić, J.; Šitić, S.; Suppan, C.; Balic, M. Chronic Oxidative Stress Promotes Molecular Changes Associated with Epithelial Mesenchymal Transition, NRF2, and Breast Cancer Stem Cell Phenotype. Antioxidants 2019, 8, 633. [CrossRef]

50. Ding, L.; Gu, H.; Xiong, X.; Ao, H.; Cao, J.; Lin, W.; Yu, M.; Lin, J.; Cui, Q. MicroRNAs Involved in Carcinogenesis, Prognosis, Therapeutic Resistance and Applications in Human Triple-Negative Breast Cancer. Cells 2019, 8, 1492. [CrossRef]

51. Chen, C.; Nelson, L.J.; Avila, M.A.; Cubero, F.J. Mitogen-Activated Protein Kinases (MAPKs) and Cholangiocarcinoma: The Missing Link. Cells 2019, 8, 1172. [CrossRef] [PubMed]

52. Manjunath, Y.; Upparahalli, S.V.; Avella, D.; Deroche, C.; Kimchi, E.; Staveley-O'Carroll, K.; Smith, C.J.; Li, G.; Kaifi, J.T. PD-L1 Expression with Epithelial Mesenchymal Transition of Circulating Tumor Cells Is Associated with Poor Survival in Curatively Resected Non-Small Cell Lung Cancer. Cancers 2019, 11, 806. [CrossRef] [PubMed]

53. Buhrmann, C. Induction of the Epithelial-to-Mesenchymal Transition of Human Colorectal Cancer by Human TNF-B (Lymphotoxin) and its Reversal by Resveratrol. Nutrients 2019, 11, 704. [CrossRef] [PubMed]

54. Boros, É.; Nagy, I. The Role of MicroRNAs upon Epithelial-to-Mesenchymal Transition in Inflammatory Bowel Disease. Cells 2019, 8, 1461. [CrossRef]

55. Sun, Z.; Cai, S.; Liu, C.; Cui, Y.; Ji, J.; Jiang, W.G.; Ye, L. Increased Expression of Gremlin1 Promotes Proliferation and Epithelial Mesenchymal Transition in Gastric Cancer Cells and Correlates with Poor Prognosis of Patients with Gastric Cancer. Cancer Genom. Proteom. 2020, 17, 49-60. [CrossRef]

56. Fedele, M.; Cerchia, L.; Pegoraro, S.; Sgarra, R.; Manfioletti, G. Proneural-Mesenchymal Transition: Phenotypic Plasticity to Acquire Multitherapy Resistance in Glioblastoma. Int. J. Mol. Sci. 2019, 20, 2746. [CrossRef]

57. Fedele, M.; Cerchia, L.; Chiappetta, G. The Epithelial-to-Mesenchymal Transition in Breast Cancer: Focus on Basal-Like Carcinomas. Cancers 2017, 9, 134. [CrossRef]

58. Fedele, M.; Cerchia, L. The Tumor Suppressive Role of PATZ1 in Thyroid Cancer: A Matter of Epithelial-Mesenchymal Transition. Chemotherapy 2016, 5, 2. [CrossRef]

59. Chiappetta, G.; Valentino, T.; Vitiello, M.; Pasquinelli, R.; Monaco, M.; Palma, G.; Sepe, R.; Luciano, A.; Pallante, P.; Palmieri, D.; et al. PATZ1 acts as a tumor suppressor in thyroid cancer via targeting p53-dependent genes involved in EMT and cell migration. Oncotarget 2015, 6, 5310-5323. [CrossRef]

60. Pegoraro, S.; Ros, G.; Piazza, S.; Sommaggio, R.; Ciani, Y.; Rosato, A.; Sgarra, R.; Del Sal, G.; Manfioletti, G. HMGA1 promotes metastatic processes in basal-like breast cancer regulating EMT and stemness. Oncotarget 2013, 4, 1293-1308. [CrossRef]

61. Tchuault, S.; Valcourt, U.; Petersen, M.; Manfioletti, G.; Heldin, C.-H.; Moustakas, A. Transforming growth factor-B employs HMGA2 to elicit epithelial-mesenchymal transition. J. Cell Biol. 2006, 174, 175-183. [CrossRef] [PubMed]

62. Yang, J.; Weinberg, R.A. Epithelial-Mesenchymal Transition: At the Crossroads of Development and Tumor Metastasis. Dev. Cell 2008, 14, 818-829. [CrossRef] [PubMed]

63. Revenu, C.; Gilmour, D. EMT 2.0: Shaping epithelia through collective migration. Curr. Opin. Genet. Dev. 2009, 19, 338-342. [CrossRef] [PubMed]

64. Repetto, O.; Paoli, P.D.; Re, V.D.; Canzonieri, V.; Cannizzaro, R. Levels of Soluble E-Cadherin in Breast, Gastric, and Colorectal Cancers. Biomed Res. Int. 2014, 2014, 1-7. [CrossRef]

65. Peng, Z. Role of epithelial-mesenchymal transition in gastric cancer initiation and progression. World J. Gastroenterol. 2014, 20, 5403. [CrossRef]

66. Raja, U.M.; Gopal, G.; Shirley, S.; Ramakrishnan, A.S.; Rajkumar, T. Immunohistochemical expression and localization of cytokines/chemokines/growth factors in gastric cancer. Cytokine 2017, 89, 82-90. [CrossRef] 
67. Federico, A.; Pallante, P.; Bianco, M.; Ferraro, A.; Esposito, F.; Monti, M.; Cozzolino, M.; Keller, S.; Fedele, M.; Leone, V.; et al. Chromobox Protein Homologue 7 Protein, with Decreased Expression in Human Carcinomas, Positively Regulates E-Cadherin Expression by Interacting with the Histone Deacetylase 2 Protein. Cancer Res. 2009, 69, 7079-7087. [CrossRef]

68. Pattabiraman, D.R.; Bierie, B.; Isabelle Kober, K.; Thiru, P.; Krall, J.; Zill, C.; Reinhardt, F.; Leong Tam, W.; Weinberg, R.A. Activation of PKA leads to mesenchymal-to-epithelial transition and loss of tumor-initiating ability One Sentence Summary We identify a novel role for the activation of PKA and downstream epigenetic reprogramming that results in the differentiation of tum. Science 2016, 351, 1-27. [CrossRef]

69. Huang, L.; Wu, R.-L.; Xu, A.-M. Epithelial-mesenchymal transition in gastric cancer. Am. J. Transl. Res. 2015, 7, 2141-2158.

70. Chen, L.; Park, S.M.; Tumanov, A.V.; Hau, A.; Sawada, K.; Feig, C.; Turner, J.R.; Fu, Y.X.; Romero, I.L.; Lengyel, E.; et al. CD95 promotes tumour growth. Nature 2010, 465, 492-496. [CrossRef]

71. Chanrion, M.; Kuperstein, I.; Barriere, C.; El Marjou, F.; Cohen, D.; Vignjevic, D.; Stimmer, L.; Paul-Gilloteaux, P.; Bieche, I.; Tavares Sdos, R.; et al. Concomitant Notch activation and p53 deletion trigger epithelial-to-mesenchymal transition and metastasis in mouse gut. Nat. Commun. 2014, 5, 5005. [CrossRef] [PubMed]

72. Katoh, M. Epithelial-mesenchymal transition in gastric cancer (Review). Int. J. Oncol. 2005, 27, 1677-1683. [PubMed]

73. Huang, J.; Xiao, D.; Li, G.; Ma, J.; Chen, P.; Yuan, W.; Hou, F.; Ge, J.; Zhong, M.; Tang, Y.; et al. EphA2 promotes epithelial-mesenchymal transition through the Wnt/beta-catenin pathway in gastric cancer cells. Oncogene 2014, 33, 2737-2747. [CrossRef] [PubMed]

74. Chen, J.; Wang, T.; Zhou, Y.C.; Gao, F.; Zhang, Z.H.; Xu, H.; Wang, S.L.; Shen, L.Z. Aquaporin 3 promotes epithelial-mesenchymal transition in gastric cancer. J. Exp. Clin. Cancer Res. 2014, 33, 38. [CrossRef]

75. Luo, B.H.; Xiong, F.; Wang, J.P.; Li, J.H.; Zhong, M.; Liu, Q.L.; Luo, G.Q.; Yang, X.J.; Xiao, N.; Xie, B.; et al. Epidermal growth factor-like domain-containing protein 7 (EGFL7) enhances EGF receptor-AKT signaling, epithelial-mesenchymal transition, and metastasis of gastric cancer cells. PLoS ONE 2014, 9, e99922. [CrossRef]

76. Zang, M.; Zhang, B.; Zhang, Y.; Li, J.; Su, L.; Zhu, Z.; Gu, Q.; Liu, B.; Yan, M. CEACAM6 promotes gastric cancer invasion and metastasis by inducing epithelial-mesenchymal transition via PI3K/AKT signaling pathway. PLoS ONE 2014, 9, e112908. [CrossRef]

77. Choi, Y.J.; Kim, N.; Chang, H.; Lee, H.S.; Park, S.M.; Park, J.H.; Shin, C.M.; Kim, J.M.; Kim, J.S.; Lee, D.H.; et al. Helicobacter pylori-induced epithelial-mesenchymal transition, a potential role of gastric cancer initiation and an emergence of stem cells. Carcinogenesis 2015, 36, 553-563. [CrossRef]

78. Liu, A.N.; Zhu, Z.H.; Chang, S.J.; Hang, X.S. Twist expression associated with the epithelial-mesenchymal transition in gastric cancer. Mol. Cell Biochem. 2012, 367, 195-203. [CrossRef]

79. Barker, M.; Huch, M.; Kujala, P.; van de Wetering, M.; Snippert, H.J.; van Es, J.H.; Sato, T.; Stange, D.E.; Begthel, H.; van den Born, M.; et al. Lgr5(+ve) stem cells drive self-renawal in the stomach and build long-lived gastric units in vitro. Cell Stem Cell 2010, 6, 25-36.

80. Yu, H.; Zeng, J.; Liang, X.; Wang, W.; Zhou, Y.; Sun, Y.; Liu, S.; Li, W.; Chen, C.; Jia, J. Helicobacter pylori promotes epithelial-mesenchymal transition in gastric cancer by downregulating programmed cell death protein 4 (PDCD4). PLoS ONE 2014, 9, e105306. [CrossRef]

81. Greaves, M. Cancer stem cells: Back to Darwin? Semin. Cancer Biol. 2010, 20, 65-70. [CrossRef] [PubMed]

82. Clevers, H. Wnt/beta-catenin signaling in development and disease. Cell 2006, 127, 469-480. [CrossRef] [PubMed]

83. De Lau, W.; Barker, N.; Low, T.Y.; Koo, B.K.; Li, V.S.; Teunissen, H.; Kujala, P.; Haegebarth, A.; Peters, P.J.; van de Wetering, M.; et al. Lgr5 homologues associate with Wnt receptors and mediate R-spondin signalling. Nature 2011, 476, 293-297. [CrossRef] [PubMed]

84. Voon, D.C.; Wang, H.; Koo, J.K.; Nguyen, T.A.; Hor, Y.T.; Chu, Y.S.; Ito, K.; Fukamachi, H.; Chan, S.L.; Thiery, J.P.; et al. Runx3 protects gastric epithelial cells against epithelial-mesenchymal transition-induced cellular plasticity and tumorigenicity. Stem Cells 2012, 30, 2088-2099. [CrossRef] [PubMed]

85. Galdiero, M.R.; Garlanda, C.; Jaillon, S.; Marone, G.; Mantovani, A. Tumor associated macrophages and neutrophils in tumor progression. J. Cell. Physiol. 2013, 228, 1404-1412. [CrossRef] [PubMed] 
86. Wang, S.C.; Chou, J.F.; Strong, V.E.; Brennan, M.F.; Capanu, M.; Coit, D.G. Pretreatment neutrophil to lymphocyte ratio independently predicts disease-specific sur vival in resectable gastroesophageal junction and gastric adenocarcinoma. Ann. Surg. 2016, 263, 292-297. [CrossRef] [PubMed]

87. Freisinger, C.M.; Huttenlocher, A. Live imaging and gene expression analysis in zebrafish identifies a link between neutrophils and epithelial to mesenchymal transition. PLoS ONE 2014, 9, 15-19. [CrossRef]

88. Li, S.; Cong, X.; Gao, H.; Lan, X.; Li, Z.; Wang, W.; Song, S.; Wang, Y.; Li, C.; Zhang, H.; et al. Tumor-associated neutrophils induce EMT by IL-17a to promote migration and invasion in gastric cancer cells. J. Exp. Clin. Cancer Res. 2019, 38, 1-13. [CrossRef]

89. Ubukata, H.; Motohashi, G.; Tabuchi, T.; Nagata, H.; Konishi, S.; Tabuchi, T. Evaluations of interferon-Y/interleukin-4 ratio and neutrophil/lymphocyte ratio as prognostic indicators in gastric cancer patients. J. Surg. Oncol. 2010, 102, 742-747. [CrossRef]

90. Clausen, F.; Behrens, H.-M.; Krźger, S.; Ršcken, C. Sexual dimorphism in gastric cancer: Tumor-associated neutrophils predict patient outcome only for women. J. Cancer Res. Clin. Oncol. 2019, 146, 53-66. [CrossRef]

91. Aksoy, E.K.; Kantarcı, S.; Torgutalp, M.; Akpınar, M.Y.; Sapmaz, F.P.; Yalçın, G.; Uzman, M.; Şimşek, G.G.; Nazlıgül, Y.; Kantarci, S.; et al. The importance of complete blood count parameters in the screening of gastric cancer. Gastroenterol. Rev. 2019, 14, 183-187. [CrossRef] [PubMed]

92. Keijsers, R.R.M.C.; Hendriks, A.; Van Erp, P.; Van Cranenbroek, B.; Van De Kerkhof, P.C.; Koenen, H.J.P.M.; Joosten, I. In vivo induction of cutaneous inflammation results in the accumulation of extracellular trap-forming neutrophils expressing ROR_t and IL-17. J. Investig. Dermatol. 2014, 134, 1276-1284. [CrossRef] [PubMed]

93. Hartupee, J.; Liu, C.; Novotny, M.; Li, X.; Hamilton, T. IL-17 Enhances Chemokine Gene Expression through mRNA Stabilization. J. Immunol. 2007, 179, 4135-4141. [CrossRef] [PubMed]

94. DeSelm, C.; Takahata, Y.; Warren, J.; Chappel, J.C.; Khan, T.; Li, X.; Liu, C.; Choi, Y.; Kim, Y.F.; Zou, W.; et al. IL-17 mediates estrogen-deficient osteoporosis in an Act1-dependent manner. J. Cell. Biochem. 2012, 113, 2895-2902. [CrossRef] [PubMed]

95. Wu, N.-L.; Huang, D.-Y.; Tsou, H.-N.; Lin, Y.-C.; Lin, W.-W. Syk Mediates IL-17-Induced CCL20 Expression by Targeting Act1-Dependent K63-Linked Ubiquitination of TRAF6. J. Investig. Derm.. 2015, 135, 490-498. [CrossRef]

96. Monin, L.; Gaffen, S. Interleukin 17 Family Cytokines: Signaling Mechanisms, Biological Activities, and Therapeutic Implications. Cold Spring Harb. Perspect. Boil. 2017, 10, a028522. [CrossRef]

97. Gaffen, S.L. Structure and signalling in the IL-17 receptor family. Nat. Rev. Immunol. 2009, 9, 556-567. [CrossRef]

98. Nguyen, P.M.; Putoczki, T.L. Could the inhibition of IL-17 or IL-18 be a potential therapeutic opportunity for gastric cancer? Cytokine 2019, 118, 8-18. [CrossRef]

99. Hu, L.; Kong, F.; Pan, Y. Association between IL-17A G197A polymorphism and gastric cancer risk: An updated meta-analysis based on 6,624 cases and 7,631 controls. Oncotargets 2018, 11, 703-710. [CrossRef]

100. Long, Z.-W. Association ofIL-17polymorphisms with gastric cancer risk in Asian populations. World J. Gastroenterol. 2015, 21, 5707. [CrossRef]

101. Zhang, W.; Gu, J.; Chen, J.; Zhang, P.; Ji, R.; Qian, H.; Xu, W.; Zhang, X. Interaction with neutrophils promotes gastric cancer cell migration and invasion by inducing epithelial-mesenchymal transition. Oncol. Rep. 2017, 38, 2959-2966. [CrossRef] [PubMed]

102. Ning, X.; Zhang, H.; Wang, C.; Song, X. Exosomes Released by Gastric Cancer Cells Induce Transition of Pericytes Into Cancer-Associated Fibroblasts. Med. Sci. Monit. 2018, 24, 2350-2359. [CrossRef] [PubMed]

103. Zhang, Q.; Chai, S.; Wang, W.; Wan, C.; Zhang, F.; Li, Y.; Wang, F. Macrophages activate mesenchymal stem cells to acquire cancer-associated fibroblast-like features resulting in gastric epithelial cell lesions and malignant transformation in vitro. Oncol. Lett. 2018, 17, 747-756. [CrossRef] [PubMed]

104. Zhang, Q.; Wang, M.; Huang, F.; Yang, T.; Cai, J.; Zhang, X.; Zhu, W.; Qian, H.; Xu, W.H. pylori infection-induced MSC differentiation into CAFs promotes epithelial-mesenchymal transition in gastric epithelial cells. Int. J. Mol. Med. 2013, 32, 1465-1473. [CrossRef] [PubMed]

105. Shiga, K.; Hara, M.; Nagasaki, T.; Sato, T.; Takahashi, H.; Takeyama, H. Cancer-associated fibroblasts: Their characteristics and their roles in tumor growth. Cancers 2015, 7, 2443-2458. [CrossRef] [PubMed] 
106. Wu, X.; Chen, X.; Zhou, Q.; Li, P.; Yu, B.; Li, J.; Qu, Y.; Yan, J.; Yu, Y.; Yan, M.; et al. Hepatocyte growth factor activates tumor stromal fibroblasts to promote tumorigenesis in gastric cancer. Cancer Lett. 2013, 335, 128-135. [CrossRef]

107. Kalluri, R.; Zeisberg, M. Fibroblasts in cancer. Nat. Rev. Cancer 2006, 6, 392-401. [CrossRef]

108. Sugimoto, H.; Mundel, T.M.; Kieran, M.W.; Kalluri, R. Identification of fibroblast heterogeneity in the tumor microenvironment. Cancer Biol. Ther. 2006, 5, 1640-1646. [CrossRef]

109. Nakajima, M.; Yoshino, S.; Kanekiyo, S.; Maeda, N.; Sakamoto, K.; Tsunedomi, R.; Suzuki, N.; Takeda, S.; Yamamoto, S.; Hazama, S.; et al. High secreted protein acidic and rich in cysteine expression in peritumoral fibroblasts predicts better prognosis in patients with resectable gastric cancer. Oncol. Lett. 2017, 15, 803-812. [CrossRef]

110. Zhi, K.; Shen, X.; Zhang, H.; Bi, J. Cancer-associated fibroblasts are positively correlated with metastatic potential of human gastric cancers. J. Exp. Clin. Cancer Res. 2010, 29, 66. [CrossRef]

111. Xu, G.; Zhang, B.; Ye, J.; Cao, S.; Shi, J.; Zhao, Y.; Wang, Y.; Sang, J.; Yao, Y.; Guan, W.; et al. Exosomal miRNA-139 in cancer-associated fibroblasts inhibits gastric cancer progression by repressing MMP11 expression. Int. J. Boil. Sci. 2019, 15, 2320-2329. [CrossRef] [PubMed]

112. Akashi, M.; Koma, Y.-I.; Shigeoka, M.; Nishio, M. Cancer as a tissue: The significance of cancer-stromal interactions in the development, morphogenesis and progression of human upper digestive tract cancer. Pathol. Int. 2018, 68, 334-352.

113. Zhou, Q.; Wu, X.; Wang, X.; Yu, Z.; Pan, T.; Li, Z.; Chang, X.; Jin, Z.; Li, J.; Zhu, Z.; et al. The reciprocal interaction between tumor cells and activated fibroblasts mediated by TNF-alpha/IL-33/ST2L signaling promotes gastric cancer metastasis. Oncogene 2019, 39, 1414-1428. [CrossRef] [PubMed]

114. Wu, X.; Tao, P.; Zhou, Q.; Li, J.; Yu, Z.; Wang, X.; Li, J.; Li, C.; Yan, M.; Zhu, Z.; et al. IL-6 secreted by cancer-associated fibroblasts promotes epithelial-mesenchymal transition and metastasis of gastric cancer via JAK2/STAT3 signaling pathway. Oncotarget 2017, 8, 20741-20750. [CrossRef] [PubMed]

115. Li, P.; Shan, J.; Chen, X.; Zhang, D.; Su, L.P.; Huang, X.Y.; Yu, B.Q.; Zhi, G.M.; Li, C.L.; Wang, Y.Q.; et al. Epigenetic silencing of microRNA-149 in cancer-associated fibroblasts mediates prostaglandin E2/interleukin-6 signaling in the tumor microenvironment. Cell Res. 2015, 25, 588-603. [CrossRef] [PubMed]

116. Tanaka, T.; Narazaki, M.; Masuda, K.; Kishimoto, T. Regulation of IL-6 in Immunity and Diseases. Regul. Cytokine Gene Expr. Immun. Dis. 2016, 79-88. [CrossRef]

117. Kumari, N.; Dwarakanath, B.S.; Das, A.; Bhatt, A.N. Role of interleukin-6 in cancer progression and therapeutic resistance. Tumor Biol. 2016, 37, 11553-11572. [CrossRef]

118. Zhang, X.; Hu, F.; Li, G.; Li, G.; Yang, X.; Liu, L.; Zhang, R.; Zhang, B.; Feng, Y. Human colorectal cancer-derived mesenchymal stem cells promote colorectal cancer progression through IL-6/JAK2/STAT3 signaling. Cell Death Dis. 2018, 9, 25. [CrossRef]

119. Zhu, L.; Cheng, X.; Shi, J.; Jiacheng, L.; Chen, G.; Jin, H.; Liu, A.B.; Pyo, H.; Ye, J.; Zhu, Y.; et al. Crosstalk between bone marrow-derived myofibroblasts and gastric cancer cells regulates cancer stemness and promotes tumorigenesis. Oncogene 2016, 35, 5388-5399. [CrossRef]

120. Lotti, F.; Jarrar, A.M.; Pai, R.K.; Hitomi, M.; Lathia, J.; Mace, A.; Gantt, G.A.; Sukhdeo, K.; DeVecchio, J.; Vasanji, A.; et al. Chemotherapy activates cancer-associated fibroblasts to maintain colorectal cancer-initiating cells by IL-17A. J. Exp. Med. 2013, 210, 2851-2872. [CrossRef]

121. Gasparics, Ç.; Kokeny, G.; Fintha, A.; Bencs, R.; Mozes, M.M.; Agoston, E.I.; Buday, A.; Ivics, Z.; Hamar, P.; Gyorffy, B.; et al. Alterations in SCAI Expression during Cell Plasticity, Fibrosis and Cancer. Pathol. Oncol. Res. 2017, 24, 641-651. [CrossRef] [PubMed]

122. Lee, K.; Yeo, S.; Sung, C.; Kim, S.H. Twist1 Is a Key Regulator of Cancer-Associated Fibroblasts. Cancer Res. 2014, 75, 73-85. [CrossRef] [PubMed]

123. Cecchi, F.; Rabe, D.C.; Bottaro, D.P. NIH Public Access Published in final edited form as: Expert Opin Ther Targets Targeting the HGF/MET signalling pathway in cancer therapy. 2013, 16, 553-572.

124. Hong, H.N.; Won, Y.J.; Shim, J.H.; Kim, H.J.; Han, S.H.; Kim, B.S.; Kim, H.S. Cancer-associated fibroblasts promote gastric tumorigenesis through EphA2 activation in a ligand-independent manner. J. Cancer Res. Clin. Oncol. 2018, 144, 1649-1663. [CrossRef] [PubMed]

125. Tang, D.; Gao, J.; Wang, S.; Ye, N.; Chong, Y.; Huang, Y.; Wang, J.; Li, B.; Yin, W.; Wang, D. Cancer-associated fibroblasts promote angiogenesis in gastric cancer through galectin-1 expression. Tumor Biol. 2015, 37, 1889-1899. [CrossRef] [PubMed] 
126. Ma, Y.; Zhu, J.; Chen, S.; Li, T.; Ma, J.; Guo, S.; Hu, J.; Yue, T.; Zhang, J.; Wang, P.; et al. Activated gastric cancer-associated fibroblasts contribute to the malignant phenotype and 5-FU resistance via paracrine action in gastric cancer. Cancer Cell Int. 2018, 18, 104. [CrossRef] [PubMed]

127. Saito, H.; Fushida, S.; Harada, S.; Miyashita, T.; Oyama, K.; Yamaguchi, T.; Tsukada, T.; Kinoshita, J.; Tajima, H.; Ninomiya, I.; et al. Importance of human peritoneal mesothelial cells in the progression, fibrosis, and control of gastric cancer: Inhibition of growth and fibrosis by tranilast. Gastric Cancer 2017, 21, 55-67. [CrossRef]

128. Wang, Z.; Ma, D.; Wang, C.; Zhu, Z.; Yang, Y.; Zeng, F.; Yuan, J.; Liu, X.; Gao, Y.; Chen, Y.; et al. Triptonide inhibits the pathological functions of gastric cancer-associated fibroblasts. Biomed. Pharmacother. 2017, 96, 757-767. [CrossRef]

129. Xu, W.; Hu, X.; Chen, Z.; Zheng, X.; Zhang, C.; Wang, G.; Chen, Y.; Zhou, X.; Tang, X.; Luo, L.; et al. Normal Fibroblasts Induce E-Cadherin Loss and Increase Lymph Node Metastasis in Gastric Cancer. PLoS ONE 2014, 9, e97306. [CrossRef]

130. Kanzawa, M.; Semba, S.; Hara, S.; Itoh, T.; Yokozaki, H. WNT5A is a Key Regulator of the Epithelial-Mesenchymal Transition and Cancer Stem Cell Properties in Human Gastric Carcinoma Cells. Pathobiology 2013, 80, 235-244. [CrossRef]

131. Wu, H.; Xu, J.B.; He, Y.L.; Peng, J.J.; Zhang, X.H.; Chen, C.Q.; Li, W.; Cai, S.R. Tumor-associated macrophages promote angiogenesis and lymphangiogenesis of gastric cancer. J. Surg. Oncol. 2012, 106, 462-468. [CrossRef] [PubMed]

132. Santos, A.; Jung, J.; Aziz, N.; Kissil, J.; PurŽ, E. Targeting fibroblast activation protein inhibits tumor stromagenesis and growth in mice. J. Clin. Investig. 2009, 119, 3613-3625. [CrossRef] [PubMed]

133. Liu, J.; Huang, C.; Peng, C.; Xu, F.; Li, Y.; Yutaka, Y.; Xiong, B.; Yang, X. Stromal fibroblast activation protein alpha promotes gastric cancer progression via epithelial-mesenchymal transition through Wnt/ B-catenin pathway. Bmc Cancer 2018, 18. [CrossRef] [PubMed]

134. Sun, F.; Feng, M.; Guan, W. Mechanisms of peritoneal dissemination in gastric cancer (Review). Oncol Lett. 2017, 14, 6991-6998. [CrossRef] [PubMed]

135. Kurashige, J.; Mima, K.; Sawada, G.; Takahashi, Y.; Eguchi, H.; Sugimachi, K.; Mori, M.; Yanagihara, K.; Yashiro, M.; Hirakawa, K.; et al. Epigenetic modulation and repression of miR-200b by cancer-associated fibroblasts contribute to cancer invasion and peritoneal dissemination in gastric cancer. Carcinogenesis 2014, 36, 133-141. [CrossRef]

136. Wang, R.; Sun, Y.; Yu, W.; Yan, Y.; Qiao, M.; Jiang, R.; Guan, W.; Wang, L. Downregulation of miRNA-214 in cancer-associated fibroblasts contributes to migration and invasion of gastric cancer cells through targeting FGF9 and inducing EMT. J. Exp. Clin. Cancer Res. 2019, 38. [CrossRef]

137. Xu, W.; Hu, X. Fibroblasts induced epithelial to mesenchymal transition of tumor cells and their extra circulation traveling behavior. Med. Hypotheses. 2016, 89, 24-27. [CrossRef]

138. Li, Q.; Zhu, C.; Ni, B.; Zhang, Z.Z.; Jiang, S.H.; Hu, L.P.; Wang, X.; Zhang, X.X.; Huang, P.Q.; Yang, Q.; et al. Lysyl oxidase promotes liver metastasis of gastric cancer via facilitating the reciprocal interactions between tumor cells and cancer associated fibroblasts. EBioMedicine 2019, 49, 157-171. [CrossRef]

139. Umakoshi, M.; Takahashi, S.; Itoh, G.; Kuriyama, S.; Sasaki, Y.; Yanagihara, K.; Yashiro, M.; Maeda, D.; Goto, A.; Tanaka, M. Macrophage-mediated transfer of cancer-derived components to stromal cells contributes to establishment of a pro-tumor microenvironment. Oncogene 2018, 38, 2162-2176. [CrossRef]

140. Najafi, M.; Hashemi Goradel, N.; Farhood, B.; Salehi, E.; Nashtaei, M.S.; Khanlarkhani, N.; Khezri, Z.; Majidpoor, J.; Abouzaripour, M.; Habibi, M.; et al. Macrophage polarity in cancer: A review. J. Cell. Biochem. 2019, 120, 2756-2765. [CrossRef]

141. Jackute, J.; Zemaitis, M.; Pranys, D.; Sitkauskiene, B.; Miliauskas, S.; Vaitkiene, S.; Sakalauskas, R. Distribution of M1 and M2 macrophages in tumor islets and stroma in relation to prognosis of non-small cell lung cancer. Bmc Immunol. 2018, 19, 1-13. [CrossRef] [PubMed]

142. Li, W.; Zhang, X.; Wu, F.; Zhou, Y.; Bao, Z.; Li, H.; Zheng, P.; Zhao, S. Gastric cancer-derived mesenchymal stromal cells trigger M2 macrophage polarization that promotes metastasis and EMT in gastric cancer. Cell Death Dis. 2019, 10, 918. [CrossRef] [PubMed]

143. Liu, L.; Ye, Y.; Zhu, X. MMP-9 secreted by tumor associated macrophages promoted gastric cancer metastasis through a PI3K/AKT/Snail pathway. Biomed. Pharm. 2019, 117, 109096. [CrossRef] [PubMed] 
144. Oku, T.; Shimada, K.; Kenmotsu, H.; Ando, Y.; Kurisaka, C.; Sano, R.; Tsuiji, M.; Hasegawa, S.; Fukui, T.; Tsuji, T. Stimulation of Peritoneal Mesothelial Cells to Secrete Matrix Metalloproteinase-9 (MMP-9) by TNF-alpha: A Role in the Invasion of Gastric Carcinoma Cells. Int. J. Mol. Sci. 2018, 19, 3961. [CrossRef]

145. Mimura, K.; Teh, J.L.; Okayama, H.; Shiraishi, K.; Kua, L.-F.; Koh, V.; Smoot, D.T.; Ashktorab, H.; Oike, T.; Suzuki, Y.; et al. PD-L1 expression is mainly regulated by interferon gamma associated with JAK-STAT pathway in gastric cancer. Cancer Sci. 2017, 109, 43-53. [CrossRef]

146. Lin, C.N.; Wang, C.J.; Chao, Y.J.; Lai, M.D.; Shan, Y.S. The significance of the co-existence of osteopontin and tumor-associated macrophages in gastric cancer progression. Bmc Cancer 2015, 15, 1-10. [CrossRef]

147. Fu, X.L.; Duan, W.; Su, C.Y.; Mao, F.Y.; Lv, Y.P.; Teng, Y.S.; Yu, P.W.; Zhuang, Y.; Zhao, Y.L. Interleukin 6 induces M2 macrophage differentiation by STAT3 activation that correlates with gastric cancer progression. Cancer Immunol. Immunother. 2017, 66, 1597-1608. [CrossRef]

148. Ohta, M.; Kitadai, Y.; Tanaka, S.; Yoshihara, M.; Yasui, W.; Mukaida, N.; Haruma, K.; Chayama, K. Monocyte chemoattractant protein-1 expression correlates with macrophage infiltration and tumor vascularity in human esophageal squamous cell carcinomas. Int. J. Cancer 2002, 102, 220-224. [CrossRef]

149. Yan, Y.; Zhang, J.; Li, J.-H.; Liu, X.; Wang, J.-Z.; Qu, H.-Y.; Wang, J.S.; Duan, X.Y. High tumor-associated macrophages infiltration is associated with poor prognosis and may contribute to the phenomenon of epithelial-mesenchymal transition in gastric cancer. Oncotargets Ther. 2016, 9, 3975-3983.

150. Cannizzaro, R.; Mongiat, M.; Canzonieri, V.; Fornasarig, M.; Maiero, S.; Re, V.D.; Todaro, F.; De Paoli, P.; Spessotto, P. Endomicroscopy and Cancer: A New Approach to the Visualization of Neoangiogenesis. Gastroenterol. Res. Pract. 2012, 2012, 1-5. [CrossRef]

151. Maiero, S.; Cannizzaro, R.; Fornasarig, M.; Magris, R.; Spessotto, P.; Mongiat, M.; Re, V.D.; Paoli, A.D.; Bertola, G.; Canzonieri, V.; et al. Angiogenesis evaluation in locally advanced colo-rectal and gastric cancers by probe-based Confocal Laser Endomicroscopy (pCLE). Annals of Oncology 2016, 27, iv48. [CrossRef]

152. Leone, P.; Buonavoglia, A.; Fasano, R.; Solimando, A.G.; Re, V.D.; Cicco, S.; Vacca, A.; Racanelli, V. Insights into the Regulation of Tumor Angiogenesis by Micro-RNAs. J. Clin. Med. 2019, 8, 2030. [CrossRef] [PubMed]

153. Che, Y.; Geng, B.; Xu, Y.; Miao, X.; Chen, L.; Mu, X.; Pan, J.; Zhang, C.; Zhao, T.; Wang, C.; et al. Helicobacter pylori-induced exosomal MET educates tumour-associated macrophages to promote gastric cancer progression. J. Cell. Mol. Med. 2018, 22, 5708-5719. [CrossRef]

154. Zhang, W.-J.; Chen, C.; Zhou, Z.-H.; Gao, S.-T.; Tee, T.J.; Yang, L.-Q.; Xu, Y.Y.; Pang, T.H.; Xu, X.Y.; Sun, Q.; et al. Hypoxia-inducible factor-1 alpha Correlates with Tumor-Associated Macrophages Infiltration, Influences Survival of Gastric Cancer Patients. J. Cancer 2017, 8, 1818-1825. [CrossRef] [PubMed]

155. Guo, J.; Yan, Y.; Yan, Y.; Guo, Q.; Zhang, M.; Zhang, J.; Goltzman, D. Tumor-associated macrophages induce the expression of FOXQ1 to promote epithelial-mesenchymal transition and metastasis in gastric cancer cells. Oncol. Rep. 2017, 38, 2003-2010. [CrossRef] [PubMed]

156. Wu, M.H.; Lee, W.J.; Hua, K.T.; Kuo, M.L.; Lin, M.T. Macrophage infiltration induces gastric cancer invasiveness by activating the B-catenin pathway. PLoS ONE 2015, 10, 1-13. [CrossRef]

157. Zhang, J.; Yan, Y.; Yang, Y.; Wang, L.; Li, M.; Wang, J.; Liu, X.; Duan, X.; Wang, J. High Infiltration of Tumor-Associated Macrophages Influences Poor Prognosis in Human Gastric Cancer Patients, Associates with the Phenomenon of EMT. Medicine 2016, 95, 1-6. [CrossRef]

158. Dvory-Sobol, H.; Sagiv, E.; Liberman, E.; Kazanov, D.; Arber, N. Supression of gastric cancer cell growth by targeting the beta-catenin/T-cell factor pathway. Cancer 2007, 109, 188-197. [CrossRef]

159. Peng, L.S.; Zhang, J.Y.; Teng, Y.S.; Zhao, Y.L.; Wang, T.T.; Mao, F.Y.; Lv, Y.P.; Cheng, P.; Li, W.H.; Chen, N.; et al. Tumor-associated monocytes/macrophages impair NK-cell function via TGF_1 in human gastric cancer. Cancer Immunol. Res. 2017, 5, 248-256. [CrossRef]

160. Sammarco, G.; Gadaleta, C.D.; Zuccal, V.; Albayrak, E.; Patruno, R.; Milella, P.; Sacco, R.; Ammendola, M.; Ranieri, G. Tumor-Associated Macrophages and Mast Cells Positive to Tryptase Are Correlated with Angiogenesis in Surgically-Treated Gastric Cancer Patients. Int. J. Mol. Sci. 2018, 19, 1176. [CrossRef]

161. Nienhuser, H.; Schmidt, T. Angiogenesis and Anti-Angiogenic Therapy in Gastric Cancer. Int. J. Mol. Sci. 2017, 19, 43. [CrossRef] [PubMed]

162. Morris, K.T.; Nofchissey, R.A.; Pinchuk, I.V.; Beswick, E.J. Chronic Macrophage Migration Inhibitory Factor Exposure Induces Mesenchymal Epithelial Transition and Promotes Gastric and Colon Cancers. PLoS ONE 2014, 9, e98656. [CrossRef] [PubMed] 
163. Sakamoto, S.; Kagawa, S.; Kuwada, K.; Ito, A.; Kajioka, H.; Kakiuchi, Y.; Watanabe, M.; Kagawa, T.; Yoshida, R.; Kikuchi, S.; et al. Intraperitoneal cancer-immune microenvironment promotes peritoneal dissemination of gastric cancer. OncoImmunology 2019, 8, e1671760. [CrossRef] [PubMed]

164. Lin, C.; He, H.; Liu, H.; Li, R.; Chen, Y.; Qi, Y.; Jiang, Q.; Chen, L.; Zhang, P.; Zhang, H.; et al. Tumour-associated macrophages-derived CXCL8 determines immune evasion through autonomous PD-L1 expression in gastric cancer. Gut 2019, 68, 1764-1773. [CrossRef] [PubMed]

165. Chen, L.; Shi, Y.; Zhu, X.; Guo, W.; Zhang, M.; Che, Y.; Tang, L.; Yang, X.; You, Q.; Liu, Z. IL-10 secreted by cancer-associated macrophages regulates proliferation and invasion in gastric cancer cells via c-Met/STAT3 signaling. Oncol. Rep. 2019, 42, 595-604. [CrossRef] [PubMed]

166. Ding, H.; Zhao, L.; Dai, S.; Li, L.; Wang, F.; Shan, B. CCL5 secreted by tumor associated macrophages may be a new target in treatment of gastric cancer. Biomed. Pharmacother. 2016, 77, 142-149. [CrossRef]

167. Li, T.; Li, B.; Sara, A.; Ay, C.; Leung, W.Y.; Zhang, Y.; Dong, Y.; Liang, Q.; Zhang, X.; Weidner, P.; et al. Docking protein-1 promotes inflammatory macrophage signaling in gastric cancer. OncoImmunology 2019, 8, e1649961. [CrossRef]

168. Wang, H.; Chen, B.; Lin, Y.; Zhou, Y.; Li, X. Legumain Promotes Gastric Cancer Progression Through Tumor-associated Macrophages In vitro and In vivo. Int. J. Biol. Sci. 2020, 16, 172-180. [CrossRef]

169. RŠihŠ, M.R.; Puolakkainen, P.A. Tumor-associated macrophages (TAMs) as biomarkers for gastric cancer: A review. Chronic Dis. Transl. Med. 2018, 4, 156-163.

170. Noy, R.; Pollard, J.W. Tumor-Associated Macrophages: From Mechanisms to Therapy. Immunity 2014, 41, 49-61. [CrossRef]

171. Maxwell, J.R.; Zhang, Y.; Brown, W.A.; Smith, C.L.; Byrne, F.R.; Fiorino, M.; Stevens, E.; Bigler, J.; Davis, J.A.; Rottman, J.B.; et al. Differential Roles for Interleukin-23 and Interleukin-17 in Intestinal Immunoregulation. Immunity 2015, 43, 739-750. [CrossRef] [PubMed]

172. Hor, Y.T.; Voon, D.C.C.; Koo, J.K.W.; Wang, H.; Lau, W.M.; Ashktorab, H.; Chan, S.L.; Ito, Y. A role for RUNX3 in inflammation-induced expression of IL23A in gastric epithelial cells. Cell Rep. 2014, 8, 50-83. [CrossRef] [PubMed]

173. Croxford, A.L.; Kulig, P.; Becher, B. IL-12-and IL-23 in health and disease. Cytokine Growth Factor Rev. 2014, 25, 415-421. [CrossRef] [PubMed]

174. Chang, A.H.; Young, S.H.; Sinnett-Smith, J.; Ne Chou, C.E.; Moro, A.; Hertzer, K.M.; Hines, O.J.; Rozengurt, E.; Eibl, G. Prostaglandin E2 activates the mTORC1 pathway through an EP4/cAMP/ PKA-and EP1/CA2+-mediated mechanism in the human pancreatic carcinoma cell line PANC-1. Am. J. Physiol. Cell Physiol. 2015, 309, 639-649. [CrossRef]

175. Grivennikov, S.I.; Wang, K.; Mucida, D.; Stewart, C.A.; Schnabl, B.; Jauch, D.; Taniguchi, K.; Yu, G.Y.; Osterreicher, C.H.; Hung, K.E.; et al. Adenoma-linked barrier defects and microbial products drive IL-23 / IL-17-mediated tumour growth. Nature 2013, 491, 254-258. [CrossRef]

176. Duvallet, E.; Semerano, L.; Assier, E.; Falgarone, G.; Boissier, M.C. Interleukin-23: A key cytokine in inflammatory diseases. Ann. Med. 2011, 43, 503-511. [CrossRef]

177. Revu, S.; Wu, J.; Henkel, M.; Rittenhouse, N.; Menk, A.; Delgoffe, G.M.; Poholek, A.C.; McGeachy, M.J. IL-23 and IL-1_ Drive Human Th17 Cell Differentiation and Metabolic Reprogramming in Absence of CD28 Costimulation. Cell Rep. 2018, 22, 2642-2653. [CrossRef]

178. Yan, J.; Smyth, M.J.; Teng, M.W.L. Interleukin (IL)-12 and IL-23 and Their Conflicting Roles in Cancer. Cold Spring Harb. Perspect. Biol. 2018, 10, a028530. [CrossRef]

179. Neurath, M.F. IL-23 in inflammatory bowel diseases and colon cancer. Cytokine Growth Factor Rev. 2019, 45, 1-8. [CrossRef]

180. Fan, Y.; Mao, R.; Yang, J. NF-kB and STAT3 signaling pathways collaboratively link inflammation to cancer. Protein and Cell 2013, 4, 176-185. [CrossRef]

181. Sikka, S.; Surana, R.; Dai, X.; Zhang, J.; Kumar, A.P.; Tan, B.K.H.; Sethi, G.; Bishayee, A. Targeting the STAT3 signaling pathway in cancer: Role of synthetic and natural inhibitors. Biochim. Et Biophys. Acta Rev. Cancer 2014, 1845, 136-154. [CrossRef]

182. Lu, R.; Zhang, Y.-G.; Sun, J. STAT3 activation in infection and infection-associated cancer. Mol. Cell. Endocrinol. 2017, 451, 80-87. [CrossRef] [PubMed]

183. Khoo, L.T.; Chen, L. Role of the cGAS-STING pathway in cancer development and oncotherapeutic approaches. Embo Rep. 2018, 19, e46935. [CrossRef] [PubMed] 
184. Yang, T.; Zhang, X.; Wang, M.; Zhang, J.; Huang, F.; Cai, J.; Zhang, Q.; Mao, F.; Zhu, W.; Qian, H.; et al. Activation of Mesenchymal Stem Cells by Macrophages Prompts Human Gastric Cancer Growth through NF-kB Pathway. PLoS ONE 2014, 9, e97569.

185. Floss, D.M.; Schršder, J.; Franke, M.; Scheller, J. Insights into IL-23 biology: From structure to function. Cytokine Growth Factor Rev. 2015, 26, 569-578. [CrossRef] [PubMed]

186. Wcislo-Dziadecka, D.; Zbiciak-Nylec, M.; Brzezinska-Wcislo, L.; Bebenek, K.; Kazmierczak, A. Newer treatments of psoriasis regarding IL-23 inhibitors, phosphodiesterase 4 inhibitors, and Janus kinase inhibitors. Dermatol. Ther. 2017, 30,1-8. [CrossRef]

187. He, H.; Guttman-Yassky, E. JAK Inhibitors for Atopic Dermatitis: An Update. Am. J. Clin. Dermatol. 2019, 20, 181-192. [CrossRef]

188. Nie, W.; Yu, T.; Sang, Y.; Gao, X. Tumor-promoting effect of IL-23 in mammary cancer mediated by infiltration of M2 macrophages and neutrophils in tumor microenvironment. Biochem. Biophys. Res. Commun. 2017, 482, 1400-1406. [CrossRef]

189. Calcinotto, A.; Spataro, C.; Zagato, E.; di Mitri, D.; Gil, V.; Crespo, M.; Bernardis, G.D.; Losa, M.; Mirenda, M.; Pasquini, E.; et al. IL-23 secreted by myeloid cells drives castration-resistant prostate cancer. Nature 2018, 559, 363-369. [CrossRef]

190. Banerjee, K.; Resat, H. Constitutive activation of STAT3 in breast cancer cells: A review. Int. J. Cancer 2016, 138, 2570-2578. [CrossRef]

191. Hadjidaniel, M.D.; Muthugounder, S.; Hung, L.T.; Sheard, M.A.; Shirinbak, S.; Chan, R.Y.; Nakata, R.; Borriello, L.; Malvar, J.; Kennedy, R.J.; et al. Tumor-associated macrophages promote neuroblastoma via STAT3 phosphorylation and up-regulation of c-MYC. Oncotarget 2017, 8, 91516-91529. [CrossRef] [PubMed]

192. Shastri, A.; Choudhary, G.; Teixeira, M.; Gordon-Mitchell, S.; Ramachandra, N.; Bernard, L.; Bhattacharyya, S.; Lopez, R.; Pradhan, K.; Giricz, O.; et al. Antisense STAT3 inhibitor decreases viability of myelodysplastic and leukemic stem cells. J. Clin. Investig. 2018, 128, 5489-5504. [CrossRef] [PubMed]

193. Gao, S.; Chen, M.; Wei, W.; Zhang, X.; Zhang, M.; Yao, Y.; Lv, Y.; Ling, T.; Wang, L.; Zou, X. Crosstalk of mTOR/PKM2 and STAT3/c-Myc signaling pathways regulate the energy metabolism and acidic microenvironment of gastric cancer. J. Cell. Biochem. 2019, 120, 1193-1202. [CrossRef] [PubMed]

194. Zhao, G.; Zhu, G.; Huang, Y.; Zheng, W.; Hua, J.; Yang, S.; Zhuang, J.; Ye, J. IL-6 mediates the signal pathway of JAK-STAT3-VEGF-C promoting growth, invasion and lymphangiogenesis in gastric cancer. Oncol. Rep. 2016, 35, 1787-1795. [CrossRef] [PubMed]

195. Xu, X.; Yang, C.; Chen, J.; Liu, J.; Li, P.; Shi, Y.; Yu, P. Interleukin-23 promotes the migration and invasion of gastric cancer cells by inducing epithelial-to-mesenchymal transition via the STAT3 pathway. Biochem. Biophys. Res. Commun. 2018, 499, 273-278. [CrossRef] [PubMed]

196. Fehlings, M.; Drobbe, L.; Moos, V.; Viveros, P.R.; Hagen, J.; Beigier-Bompadre, M.; Pang, E.; Belogolova, E.; Churin, Y.; Schneider, T.; et al. Comparative analysis of the interaction of Helicobacter pylori with human dendritic cells, macrophages, and monocytes. Infect. Immun. 2012, 80, 2724-2734. [CrossRef]

197. Caruso, R.; Pallone, F.; Monteleone, G. Emerging role of IL-23/IL-17 axis in H pylori-associated pathology. World J. Gastroenterol. 2007, 13, 5547-5551. [CrossRef]

198. Zhang, B.; Rong, G.; Wei, H.; Zhang, M.; Bi, J.; Ma, L.; Xue, X.; Wei, G.; Liu, X.; Fang, G. The prevalence of Th17 cells in patients with gastric cancer. Biochem. Biophys. Res. Commun. 2008, 374, 533-537. [CrossRef]

199. Vivas, J.R.; Regnault, B.; Michel, V.; Bussiere, F.I.; Ave, P.; Huerre, M.; Labigne, A.; D’Elios, M.M.; Touati, E. Interferon gamma-signature transcript profiling and IL-23 upregulation in response to Helicobacter pylori infection. Int. J. Immunopathol. Pharm. 2008, 21, 515-526. [CrossRef]

200. Iida, T.; Iwahashi, M.; Katsuda, M.; Ishida, K.; Nakamori, M.; Nakamura, M.; Naka, T.; Ojima, T.; Ueda, K.; Hayata, K.; et al. Tumor-infiltrating CD4+ Th17 cells produce IL-17 in tumor microenvironment and promote tumor progression in human gastric cancer. Oncol. Rep. 2011, 25, 1271-1277.

201. Rocha, G.A.; de Melo, F.F.; Cabral, M.M.D.A.; de Brito, B.B.; da Silva, F.A.F.; Queiroz, D.M.M. Interleukin-27 is abrogated in gastric cancer, but highly expressed in other Helicobacter pylori-associated gastroduodenal diseases. Helicobacter 2019, 25, 1-9. [CrossRef]

202. Altobelli, A.; Bauer, M.; Velez, K.; Cover, T.L.; Mźller, A. Helicobacter pylori VacA targets myeloid cells in the gastric lamina propria to promote peripherally induced regulatory T-cell differentiation and persistent infection. mBio 2019, 10, 1-13. [CrossRef] [PubMed] 
203. Dong, K.; Xu, Y.; Yang, Q.; Shi, J.; Jiang, J.; Chen, Y.; Song, C.; Wang, K. Associations of Functional MicroRNA Binding Site Polymorphisms in IL23/Th17 Inflammatory Pathway Genes with Gastric Cancer Risk. Mediat. Inflamm. 2017, 2017. [CrossRef] [PubMed]

204. He, B.; Pan, B.; Pan, Y.; Wang, X.; Zhou, L.; Sun, H.; Xu, T.; Xu, X.; Liu, X.; Wang, S. Polymorphisms of IL-23R predict survival of gastric cancer patients in a Chinese population. Cytokine 2019, 117, 79-83. [CrossRef] [PubMed]

205. Liu, C.; Zhang, Y.; Zhan, J.; Zhao, Y.; Wan, Q.; Peng, H.; Zhu, W. Interleukin-23A is associated with tumor growth in Helicobacter-pylori-related human gastric cancer. Cancer Cell Int. 2014, 14, 1-9. [CrossRef] [PubMed]

206. Chung, H.W.; Kim, J.J.; Choi, J.I.; Lee, H.R.; Lim, J.B. A disintegrin and metalloproteinase 8 as a potential blood biomarker for early diagnosis of gastric cancer. Yonsei Med. J. 2019, 60, 713-719. [CrossRef] [PubMed]

207. Blogowski, W.; Madej-Michniewicz, A.; Marczuk, N.; Dolegowska, B.; Starzynska, T. Interleukins 17 and 23 in patients with gastric neoplasms. Sci. Rep. 2016, 6, 6-13. [CrossRef]

208. Hoffmann, W. Current Status on Stem Cells and Cancers of the Gastric Epithelium. Int. J. Mol. Sci. 2015, 16, 19153-19169. [CrossRef]

209. Berger, L.; Shamai, Y.; Skorecki, K.L.; Tzukerman, M. Tumor Specific Recruitment and Reprogramming of Mesenchymal Stem Cells in Tumorigenesis. Stem Cells 2016, 34, 1011-1026. [CrossRef]

210. Xue, Z.; Wu, X.; Chen, X.; Liu, Y.; Wang, X.; Wu, K.; Nie, Y.; Fan, D. Mesenchymal Stem Cells Promote Epithelial to Mesenchymal Transition and Metastasis in Gastric Cancer Though Paracrine Cues and Close Physical Contact. J. Cell. Biochem. 2015, 116, 618-627. [CrossRef]

211. Puculek, M.; Baj, J.; Portincasa, P.; Sitarz, M.; Grochowski, C.; Radzikowska, E. The morphology and application of stem cells in digestive system surgery. Folia Morphol. 2020, 11. [CrossRef] [PubMed]

212. Shi, Y.; Du, L.; Lin, L.; Wang, Y. Tumour-associated mesenchymal stem/stromal cells: Emerging therapeutic targets. Nat. Rev. Drug Discov. 2016, 16, 35-52. [CrossRef] [PubMed]

213. Zheng, Y.; Wang, G.; Chen, R.; Hua, Y.; Cai, Z. Mesenchymal stem cells in the osteosarcoma microenvironment: Their biological properties, influence on tumor growth, and therapeutic implications. Stem Cell Res. Ther. 2018, 9, 1-9. [CrossRef] [PubMed]

214. Motegi, S.-I.; Ishikawa, O. Mesenchymal stem cells: The roles and functions in cutaneous wound healing and tumor growth. J. Dermatol. Sci. 2017, 86, 83-89. [CrossRef]

215. Ridge, S.M.; Sullivan, F.J.; Glynn, S.A. Mesenchymal stem cells: Key players in cancer progression. Mol. Cancer 2017, 16, 1-10. [CrossRef]

216. Papaccio, F.; Paino, F.; Regad, T.; Papaccio, G.; Desiderio, V.; Tirino, V. Concise Review: Cancer Cells, Cancer Stem Cells, and Mesenchymal Stem Cells: Influence in Cancer Development. Stem Cells Transl. Med. 2017, 6, 2115-2125. [CrossRef]

217. Patidar, M.; Yadav, N.; Dalai, S.K. Interleukin 15: A key cytokine for immunotherapy. Cytokine Growth Factor Rev. 2016, 31, 49-59. [CrossRef]

218. Chen, Y.; Chen, B.; Yang, T.; Xiao, W.; Qian, L.; Ding, Y.; Ji, M.; Ge, X.; Gong, W. Human fused NKG2D-IL-15 protein controls xenografted human gastric cancer through the recruitment and activation of NK cells. Cell. Mol. Immunol. 2017, 14, 293-307. [CrossRef]

219. Wang, W.; Jin, J.; Dai, F.; Long, Z.; Liu, X.; Cai, H.; Zhou, Y.; Chen, Z.; Huang, H. Interleukin-15 suppresses gastric cancer liver metastases by enhancing natural killer cell activity in a murine model. Oncol. Lett. 2018, 16, 4839-4846. [CrossRef]

220. Sun, L.; Wang, Q.; Chen, B.; Zhao, Y.; Shen, B.; Wang, X.; Zhu, M.; Li, Z.; Zhao, X.; Xu, C.; et al. Human gastric cancer mesenchymal stem cell-derived IL15 contributes to tumor cell epithelial-mesenchymal transition via upregulation tregs ratio and PD-1 Expression in CD4+T Cell. Stem Cells Dev. 2018, 27, 1203-1214. [CrossRef]

221. Reiser, J.; Banerjee, A. Effector, Memory, and Dysfunctional CD8+ T Cell Fates in the Antitumor Immune Response. Journal of Immunology Research. J. Immunol. Res. 2016, 2016, 8941260. [CrossRef] [PubMed]

222. Zhang, L.; Romero, P. Metabolic Control of CD8 + T Cell Fate Decisions and Antitumor Immunity. Trends Mol. Med. 2018, 24, 30-48. [CrossRef] [PubMed]

223. Qian, X.; Chen, H.; Wu, X.; Hu, L.; Huang, Q.; Jin, Y. Interleukin-17 acts as double-edged sword in anti-tumor immunity and tumorigenesis. Cytokine 2017, 89, 34-44. [CrossRef] [PubMed] 
224. Goebel, L.; Grage-Griebenow, E.; Gorys, A.; Helm, O.; Genrich, G.; Lenk, L.; Wesch, D.; Ungefroren, H.; Freitag-Wolf, S.; Sipos, B.; et al. CD4+ T cells potently induce epithelialmesenchymal- transition in premalignant and malignant pancreatic ductal epithelial cells-novel implications of CD4+ T cells in pancreatic cancer development. OncoImmunology 2015, 4, 1-15. [CrossRef]

225. Liu, X.; Yu, H.; Yan, C.; Mei, Y.; Lin, C.; Hong, Y.; Lin, X.; Zhang, Q.; Yu, J. Plasmacytoid Dendritic Cells and ICOS Regulatory T Cells Predict Poor Prognosis in Gastric Cancer: A Pilot Study. J. Cancer 2019, 10, 6711-6715. [CrossRef]

226. Wang, M.; Chen, B.; Sun, X.-X.; Zhao, X.-D.; Zhao, Y.-Y.; Sun, L.; Xu, C.C.; Shen, B.; Su, Z.L.; Xu, W.R.; et al. Gastric cancer tissue-derived mesenchymal stem cells impact peripheral blood mononuclear cells via disruption of Treg/Th17 balance to promote gastric cancer progression. Exp. Cell Res. 2017, 361, 19-29. [CrossRef]

227. Saito, H.; Shimizu, S.; Kono, Y.; Murakami, Y.; Shishido, Y.; Miyatani, K.; Matsunaga, T.; Fukumoto, Y.; Ashida, K.; Fujiwara, Y. PD-1 expression on circulating CD8 + T-cells as a prognostic marker for patients with gastric cancer. Anticancer Res. 2019, 39, 443-448. [CrossRef]

228. Liu, F.; Bu, Z.; Zhao, F.; Xiao, D. Increased T-helper 17 cell differentiation mediated by exosome-mediated microRNA-451 redistribution in gastric cancer infiltrated T cells. Cancer Sci. 2018, 109, 65-73. [CrossRef]

229. Kindlund, B.; Sjoling, A.; Yakkala, C.; Adamsson, J.; Janzon, A.; Hansson, L.E.; Hermansson, M.; Janson, P.; Winqvist, O.; Lundin, S.B. CD4+ regulatory T cells in gastric cancer mucosa are proliferating and express high levels of IL-10 but little TGF-B. Gastric Cancer 2017, 20, 116-125. [CrossRef]

230. Li, F.; Sun, Y.; Huang, J.; Xu, W.; Liu, J.; Yuan, Z. CD4/CD8 T cells, DC subsets, Foxp3, and IDO expression are predictive indictors of gastric cancer prognosis. Cancer Med. 2019, 8, 7330-7344. [CrossRef]

231. Alexandrov, L.B.; Nik-Zainal, S.; Wedge, D.C.; Aparicio, S.A.; Behjati, S.; Biankin, A.V.; Bignell, G.R.; Bolli, N.; Borg, A.; Borresen-Dale, A.L.; et al. Signatures of mutational processes in human cancer. Nature 2013, 500, 415-421. [CrossRef] [PubMed]

232. Gajewski, T.F.; Schreiber, H.; Fu, Y.X. Innate and adaptive immune cells in the tumor microenvironment. Nat. Immunol. 2013, 14, 1014-1022. [CrossRef] [PubMed]

233. Lee, H.E.; Chae, S.W.; Lee, Y.J.; Kim, M.A.; Lee, H.S.; Lee, B.L.; Kim, W.H. Prognostic implications of type and density of tumour-infiltrating lymphocytes in gastric cancer. Br. J. Cancer 2008, 99, 1704-1711. [CrossRef] [PubMed]

234. Lee, K.; Hwang, H.; Nam, K.T. Immune response and the tumor microenvironment: How they communicate to regulate gastric cancer. Gut Liver 2014, 8, 131-139. [CrossRef]

(C) 2020 by the authors. Licensee MDPI, Basel, Switzerland. This article is an open access article distributed under the terms and conditions of the Creative Commons Attribution (CC BY) license (http://creativecommons.org/licenses/by/4.0/). 